\title{
The Bioarchaeology of Kinship Proposed Revisions to Assumptions Guiding Interpretation
}

\author{
by Bradley E. Ensor, Joel D. Irish, and William F. Keegan
}

\begin{abstract}
Bioarchaeology provides sophisticated techniques for estimating intra- and intercemetery biological relationships (i.e., biodistances), which can significantly expand anthropological research on kinship, explaining multiple dimensions of social life and identity in prehistory. However, some assumptions guiding the interpretation of results may need reconsideration. Although it is often assumed that descent groups should be homogeneous, social organizational and marriage practices actually produce heterogeneity within descent groups. Interpretations of postmarital residence typically assume that spouses are buried together in the same cemetery, whereas cross-cultural ethnographic patterns suggest that postmortem location does not universally follow residence. Nevertheless, cross-cultural data do indicate that postmortem location is generally predictable by type of descent group and whether membership with natal groups is maintained or transferred upon marriage. These issues are discussed, leading to alternative models on intra- and intercemetery biodistance expectations for matrilineal descent groups, for patrilineal descent groups with and without wives' membership transfers, and for a range of smaller groups under bilateral descent. The influence of common marriage alliance systems on intra- and intergroup phenotypic heterogeneity versus homogeneity are also described. The proposed biodistance expectations for interpreting different kinship and marriage strategies may better position bioarchaeologists to engage other subfields and make substantial contributions to kinship research.
\end{abstract}

Kinship persists as an essential anthropological subject. It has an inextricable relationship with sociopolitical organization, production, and distribution; gender relations; spirituality; and identity. Kinship is therefore critical to understanding any past society and the changes impacting the social fabric of human lives from an anthropological perspective.

Although frequently portrayed as a disappearing cognitive or structural-functionalist subject in anthropology, kinship research actually became a critical component in research on political economy and gender relations in the 1970s (Peletz 1995). After a period of critique (e.g., Franklin and McKinnon 2001; Gillespie 2000a, 2000b; Kuper 1982), the subject remained important to political economic and gender theory and to postmodern perspectives on identity (e.g., Collier and Yanagisako 1987; Ellison 2009; Ensor 2011; Godelier 2011; Hutchinson 1996; McKnight 2004; Sahlins 2013). Using middle-range approaches, archaeological kinship analysis interprets postmarital residence and descent to address context-based social or-

Bradley E. Ensor is Professor in the Department of Sociology, Anthropology, and Criminology of Eastern Michigan University (Ypsilanti, Michigan 48197, USA [bensor@emich.edu]). Joel D. Irish is Professor at the Research Centre in Evolutionary Anthropology and Paleoecology of Liverpool John Moores University (Liverpool L3 3AF, United Kingdom). William F. Keegan is Curator of Caribbean Archaeology at the Florida Museum of Natural History at the University of Florida (Gainesville, Florida 32611, USA). This paper was submitted 1 IX 15, accepted 5 IX 16, and electronically published 10 X 17. ganizational strategies and the negotiation of gender relations and identities (Ensor 2013a, 2013b). Meanwhile, recent linguistic approaches to ethnographic kin-term semantics attempt to "reconstruct" prehistoric kinship with interpretations guided by phylogenetic models and historical particularism (e.g., Jones and Milicik 2011; McConvell, Keen, and Hendery 2013).

Bioarchaeology has great potential to provide new interpretations of prehistoric kinship (see Stojanowski and Schillaci [2006] for a thorough review) and independently test ethnological, archaeological, and linguistic interpretations and theoretical models. However, only archaeology and bioarchaeology have access to data that date to the prehistoric periods in question. The development of kinship analysis in both subfields is therefore necessary for cotesting interpretations and contributing long-term perspectives. Within the current period of anthropology, no subfield has maintained rigorous methodological development, analytical techniques, and attention to understanding its data to a higher degree than biological anthropology and, specifically, bioarchaeology. As such, the latter stands in an excellent position to contribute to and potentially guide broader kinship research across anthropology.

The subfield of bioarchaeology is methodologically rich in terms of using human skeletal remains to estimate biological relationships, or biodistances. Specifically, the latter can be obtained by using a range of model-free and model-bound methods to characterize and compare phenotypic (i.e., metric) and morphological (i.e., nonmetric) dental, cranial, and even postcranial variables (e.g., Bedrick, Lapidus, and Powell 
2000; Irish 2010; Konigsberg 1990, 2006; Relethford and Blangero 1990; Relethford and Lees 1982; Sjøvold 1977; Stojanowski and Schillaci 2006). However, some unacknowledged or unrecognized conceptual problems guiding estimates of biodistances may inhibit the potential for communicating across subfields. These problems include the persistence of a longdiscarded biological perspective; unreliable assumptions concerning kin group compositions, postmarital residence, and cemetery populations; and insufficient attention to marriage systems. In response, this essay provides revised interpretations for patterns in phenotype variation and biodistance resulting from different social organization and marriage strategies. Improvements in conceptualization of what patterns represent in terms of kinship would allow bioarchaeologists to better interpret phenotype distributions and better engage in intersubfield research on this topic. As a step toward this goal, perceived problems are discussed, points concerning kin group compositions and postmarital residence are clarified, revised models for interpreting phenotype data are presented, and the likely effects of marriage systems on gene flow are outlined. Before proceeding, however, a common point of reference is useful. This focus here is on intra- and intercemetery biodistance analyses. These two categories are equivalent to the most specific of six geographic levels of analysis recognized by Scott and Turner (1997): individual, "family," and local, which entails different settlements within regions. The other three levels (i.e., interregional, continental, and global), which are broader, are little affected by variability in kinship patterns.

\section{Assumptions Guiding Interpretation}

Recurring problems in bioarchaeological kinship analyses involve neither the data nor the analytical techniques but rather the conceptual frameworks for interpretation. An anthropologically rejected understanding of kinship as biological relatedness persists to some degree in bioarchaeology. Traditional assumptions that descent groups are biologically homogeneous inaccurately portray their social compositions. Models for interpreting postmarital residence mistakenly assume that spouses are universally buried together. Furthermore, there appears to be a lack of sufficient attention to marriage systems that govern gene flow and phenotype distributions within and across kin groups. These problems suggest a need to revise biodistance expectations for interpreting kinship strategies.

Bioarchaeological approaches to kinship have a long, impressive history of attention to methodology and data for estimating biological relationships based on phenotypic as well as genetic methods. Perhaps because of this focus, "kinship" largely became the subject of biological relatedness to identify loose concepts of "family" (e.g., Alt and Vach 1995, 1998; Alt et al. 1997). A biological perspective on kinship also occurs in other biologically oriented fields and theoretical genres (e.g., evolutionary psychology, sociobiology, and genetics). However, this biological perspective on kinship has been continuously critiqued in all anthropological theoretical paradigms since the 1950s (e.g., Fortes 1959:149; Fox 1967; Gjessing 1956; LéviStrauss 1956; Sahlins 2013; Schneider 1984). For most anthropologists of the past half century, kin groups and marriage practices are viewed as socially constituted. Nevertheless, in a recent conference symposium with the contemporary goal to "move beyond the archaeological identification of biological kin to assessing social organization by exploring the interconnectivity of individual, kin-level, and population-level social identities" (Johnson and Paul 2014), six of 14 presentations still explicitly or implicitly emphasized kinship as the subject of biological relatedness (Ensor 2014). One social anthropologist recently noted, in discussing another symposium, that bioarchaeologists are too often nonreflexive, projecting Western notions of biological relatedness into their questions on and analyses of what are actually nonbiologically constituted social groups (Meyer 2014). There is also occasional confusion over terminology, such as the use of "lineage" to denote biological descent, the use of "affinity" as if kin groups were isolated from marriage and hence gene flow, and the use of "family" as a universal construction (as above). These influences from biological perspectives suggest a lingering disconnect between bioarchaeological and anthropological perspectives.

Such inconsistencies with anthropological understandings can inhibit intersubfield communication and lead to problematic assumptions guiding interpretations. For example, descent groups (i.e., members of lineages or clans) are frequently assumed to be biologically homogeneous (e.g., Howell and Kintigh 1996; Stojanowski and Scillaci 2006:53-64). In contrast, the social makeup of descent groups should prevent internal homogeneity. Figure 1 shows a hypothetical genealogy. The first point illustrated is that unilineal descent groups are not a collection of close biological relatives. The shaded matrilineally related individuals composing a small matrilineage show small clusters of individuals with close biological relations; however, there are more distant biological relations among clusters. When those men and women are buried in the same matrilineage cemetery, phenotypes would exhibit intracemetery heterogeneity, especially considering gene flow through parents of other groups. If space provided a larger matrilineage or matriclan to illustrate, the figure would show even greater biological heterogeneity among members. The second point illustrated in the figure is that many close biological relatives do not share matrilineage membership and would therefore be buried in different descent group cemeteries. Thus, close biological relationships should be spread across descent group cemeteries, not concentrated within.

Although much attention has been paid to phenotypic traits and quantitative methods that lend themselves to kinship analysis (Konigsberg 1988; Schillaci and Stojanowski 2003; Stojanowski and Schillaci 2006; Tomczak and Powell 2003), less attention has been given to models for interpreting kinship behaviors, including assumptions about postmarital residence. For example, it is often assumed that spouses are buried together where they lived. Thus, within cemeteries, greater variation among males than females is thought to indicate matrilocality/uxorilocality, greater variation among females than males 


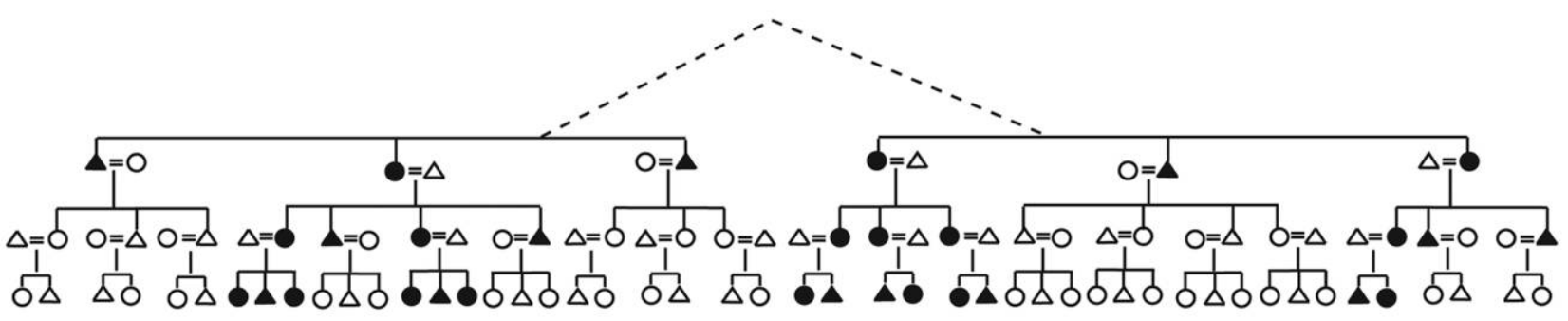

Figure 1. Diagram of a biologically related collection of individuals. Only those shaded belong to one matrilineage. Those not shaded belong to a number of additional matrilineages and would be buried in different cemeteries. Some members of the shaded matrilineage are closely related biologically, whereas other members have distant biological relations. Regardless, the men and women of that matrilineage should be buried together in the same cemetery, resulting in multiple small clusters of men and women with low biodistances but with greater intercluster biodistances. Meanwhile, some close biological relations belong to completely different lineages, resulting in low biodistances among small clusters among different lineage cemeteries.

suggests patrilocality/virilocality, and significant variation in both sexes indicates biolocality (e.g., Konigsberg 1988; Lane and Sublett 1972; Schillaci and Stojanowski 2003; Spence 1974; Tomczak and Powell 2003). Alternatively, through the same assumption, others suggest that postmarital residence may be detected by low intercemetery biodistances within one sex: matrilocality if males show less variation or patrilocality if females have less variation across groups' cemeteries (e.g., Aguiar and Neves 1991; Hubbe et al. 2009). The assumption that spouses are buried together is certainly supported by many ethnographic examples. At the same time, however, ethnographic literature provides many examples of the deceased being returned to their own descent groups' cemeteries as a preference or rule (e.g., Keegan 2009). Thus, the linkage of burial location with postmarital residence is not universally supported. Nevertheless, this problem may be remedied by identifying the types of kinship strategies associated with spouse coburial. If certain organizational strategies are predictably associated with spouse coburial and others are not, then bioarchaeologists could expand their interpretations beyond postmarital residence.

To illustrate, the Electronic Human Relations Area Files (eHRAF) database was accessed to examine crosscultural variation in postmortem location. A search of the eHRAF database using "All Cultures-and-Kin Groups \& Kinship-and-Cemeter*" yielded 161 paragraphs in 115 documents for 68 cultures. Among them, ethnographic information on postmortem location practices of 28 cultures was obtained. The descriptions were examined for group membership, cemetery affiliation, postmortem location, and whether spouses transferred their membership upon marriage. As table 1 illustrates, in all cultures of this sample having matrilineal descent groups, people were buried in their descent group cemeteries. Despite matrilocality, men were returned to their groups for burial and not interred in their wives' group cemeteries. In the cultures with patrilineal descent, women were also buried in their descent group cemetery. They were only buried in the same cemetery as their husbands if their membership was transferred to the husbands' groups upon marriage. Only in cultures with bilateral descent are spouses predictably buried together in the same cemetery. These data suggest that postmortem location is instead influenced by descent group membership or the use of bilateral descent.

A promising direction in bioarchaeology is the use of biocultural data to identify or test how cemeteries were socially constituted to ideologically reproduce identities and social relations (e.g., Bouwman 2014; Marshall 2014; Seidel and Nado 2014; Usher and Weets 2014; Zakrzewski 2014). This approach overcomes a potentially faulty assumption about what the cemetery units represent. However, this approach still needs improved models to make interpretations on specific kinship strategies enabling conclusions on the negotiation of corporate organization, gender relationships, and identity construction.

Another objective of this article is to illustrate the importance of marriage systems on phenotype distributions within and across kin groups. Marriage prescriptions and proscriptions reproduce social organization. Unilineal descent groups must emphasize exogamy, despite most comembers' distant biological relatedness, to maintain their unilineal principles for membership and resource ownership in addition to creating necessary alliances with other groups (Fox 1967). Beyond exogamy, some marriage systems promote "inbreeding" of two groups that exclusively exchange spouses across generations. Others spread marital partners in unidirectional manners from one group to another, resulting in gene flow among all groups. Others prevent individuals from marrying members of certain groups, despite the fact that most within those groups are not biologically related. Additional systems are individual, rather than group, based; they could promote potentially random marriage distributions, yet strategic preferences for alliances and resource security produce patterns. While most children are conceived through marriages, thus inheriting alleles from spouses, marriage systems equally govern premarital behaviors toward courtship and thus phenotypes of children born outside marriages. Essentially, marriage systems govern gene flow, underscoring the fact that phenotypes and their distributions are biocultural phenomena structured by marriage systems as well as social organization. 
Table 1. Sample of 28 cultures, illustrating cemetery organization and postmortem location by kinship strategy

\begin{tabular}{|c|c|c|}
\hline Descent/descent group & Cemetery and postmortem location & Culture(s) \\
\hline Matrilineal descent groups & $\begin{array}{l}\text { In natal matrilineal descent group cemetery: men } \\
\text { are returned to their group's cemetery despite } \\
\text { matrilocality }\end{array}$ & $\begin{array}{l}\text { Iroquois in the 1930s-1940s (Fenton 1951); Akan } \\
\text { (Ashante) in the 1920s-1940s (Fortes 1950; Rattray } \\
\text { 1929); Saramaka in the 1960s (Price 1975); Goajiro } \\
\text { in the 1940s (Gutierrez de Pineda and Muirden } \\
\text { 1948); Marshallese in the 1930s (Wedgwood 1943); } \\
\text { Western Apache (Cibecue) in the nineteenth cen- } \\
\text { tury to 1950s (Kaut 1957); Tlingit from the eigh- } \\
\text { teenth to twentieth centuries (De Laguna 1972); } \\
\text { Ndyuka in the 1940s-1950s (Hurault and Winchell } \\
\text { 1961) }\end{array}$ \\
\hline $\begin{array}{l}\text { Patrilineal descent groups, whereby } \\
\text { women maintain membership in } \\
\text { their natal group }\end{array}$ & $\begin{array}{l}\text { In natal patrilineal descent group cemetery: women } \\
\text { are returned to their group's cemetery despite } \\
\text { patrilocality }\end{array}$ & Tallensi (Fortes 1945) \\
\hline $\begin{array}{l}\text { Patrilineal descent groups, whereby } \\
\text { women's membership is trans- } \\
\text { ferred to husbands' groups }\end{array}$ & $\begin{array}{l}\text { In men's patrilineal descent group cemetery } \\
\text { (includes both spouses) }\end{array}$ & $\begin{array}{l}\text { Shluh (Hoffman 1967); Pashtun in the 1950s-1970s } \\
\text { (Ahmed 1980; Barth 1965); Korean rural lineages } \\
\text { in the nineteenth century to 1970s (Han 1970; Hough } \\
\text { 1899; Janelli and Janelli 1982); Monguor in the } \\
\text { 1910s-1940s (Schram 1932, 1954); Serbs in the } \\
\text { twentieth century (Filipovic 1982); Palestinians in } \\
1960 \text { (Lutfiyya 1966) }\end{array}$ \\
\hline Patrilineal descent groups & $\begin{array}{l}\text { In patrilineal descent group cemeteries, but no } \\
\text { ethnographer's statement regarding the mem- } \\
\text { bership and burial locations for married women }\end{array}$ & $\begin{array}{l}\text { Mongo in the 1930s (Hulstaert and Vizedom 1938); } \\
\text { Igbo (Bastian 1992); Nenets in the nineteenth cen- } \\
\text { tury (Prokof eva et al. 1964); Nivkh in the } \\
\text { nineteenth century (Shternberg 1933); Samoyed in } \\
\text { the nineteenth century (Kopytoff et al. 1955); Ay- } \\
\text { mara in the 1950s (Cole 1969) }\end{array}$ \\
\hline Bilateral descent & $\begin{array}{l}\text { In cemetery used by residential groups (includes } \\
\text { both spouses), regardless of type of postmarital } \\
\text { residence }\end{array}$ & $\begin{array}{l}\text { Lozi: bilocal postmarital residence (Gluckman 1941); } \\
\text { Highland Scotts in the 1970s: neolocal postmarital } \\
\text { residence (Parman 1972); Greek refugees in the } \\
\text { 1980s: neolocal postmarital residence (Hirschon } \\
\text { 1989); Cuna: matrilocal postmarital residence (Stout } \\
\text { 1947); Bella Coola: patrilocal postmarital residence } \\
\text { (Mcllwraith 1948); Tzeltal in the 1950s: patrilocal } \\
\text { postmarital residence (Hunt 1962); Tongan } \\
\text { commoners in the 1930s: patrilocal postmarital } \\
\text { residence (Beaglehole 1941) }\end{array}$ \\
\hline
\end{tabular}

Despite problems and omissions guiding interpretation, bioarchaeology has great potential to contribute to kinship research. Some reconceptualization and a fuller understanding of social organization and marriage with which to adapt the existing methodological toolkits should lead to more developed research. Thus, the goals here are to clarify and illuminate (1) the social dimensions of different categories of corporate kin groups and marriage systems, (2) how these different strategies govern the distribution of biologically related individuals within and across groups, and most importantly (3) how those strategies variably structure postmortem location, so that bioarchaeologists may pair their biodistance results with more ethnographically consistent models for interpretation.

\section{Social Organization}

This section summarizes major forms of kinship-based social organization as a reminder or clarification of what is at stake when making interpretations, leading into the expectations for postmortem location and implications on intracemetery biodistance patterns. We intentionally avoid using terms such as "family," because they are too general and variably perceived to be analytically meaningful. We use "kin" or "relatives" only in a general sense but always with specification of what kinds of kin are referenced. An appendix provides a guide to terminology used herein, containing notes on distinctions and relations between the social and the biological (for a more comprehensive glossary, see Ensor 2013a). Emphasis is instead placed on the distinction between corporate and coresiding groups. Although mid-twentieth-century kinship research emphasized numerous distinctions based on trivial classifactory differences (e.g., lineages, sibs, clans, descent groups, and so on), simplification eventually emerged whereby "lineage" and "clan" now merely reference lower- and higher-order unilineal descent groups, no matter how these are used in a specific context (e.g., Fox 1967:50). Although most individuals within lineages and clans are not closely related biologically, the descent groups variably provide members with resources for making a living, 
mutual assistance, spiritual associations, and collective identities along with elder/leader authority over junior men and women for group success and perpetuation (Fox 1967; Keesing 1975; Scheffler 2001). Most biologically related kindred relatives are unimportant in these regards but may be used for secondary rights. In contrast, bilateral descent emphasizes networks of biological kindred and affinal relations, rather than exclusive corporate group strategies, for negotiating - through more numerous relationships - access to resources, mutual assistance, and identities. However, embedded within those networks, societies may emphasize any residential strategy from a wide range of alternatives.

Matrilineal household groups are small unilineal corporate groups that provide members with resources for making a living, mutual support, and collective identities (Ensor 2013a; Fox 1967; Keesing 1975). They consist of a set of adult siblings, their mothers and mothers' siblings, their matrilineal parallel cousins, and their children and female parallel cousins' children. Matrilineages and/or matriclans are larger corporate descent groups with exclusive memberships along matrilineal principles entailing rights to resources, mutual support, and collective identities. More numerous, including more biologically distant, sets of matrilineal parallel cousins (emically referred to as sisters and brothers) make up these large corporate descent groups. Most of an individual's biologically related kindred relatives are excluded from his or her matrilineal descent groups. In some societies, subclan lineages provide resources and spirit associations, whereas clans sponsor specific ceremonies for the rest of the society. However organized among descent groups, ceremonies require surplus production (for gifts and feasts) and inherited or achieved leadership roles. In societies with internal descent group ranking, leadership is passed to members of the descent group, not necessarily through primogeniture or to a specific gender, but through matrilineal descent (Keegan 2006). The matrilineages or matriclans must maintain exogamy to perpetuate this strategy for group membership. Descent group names enable individuals to immediately recognize how they can interact with others in terms of avoidance, joking, premarital sex, courtship, and marriage without needing to know everyone's genealogies.

Matrilocal residential groups reproduce the corporate household group through postmaritally mobile husbands, who remain members of their own household groups but labor for and contribute to the reproduction of their wives' household groups. Although situations in which men are frequently away from settlements have been argued to cause matrilocality (e.g., Ember and Ember 1971), the leading hypothesis is a need to localize women's engendered division of labor (Driver and Massey 1957; Fox 1967:77-85; Gough 1961:551-564; Korotayev 2003). When matrilineal descent groups have exclusive settlements, the local groups consist of the collection of matrilocal residential groups. Although present, men do not belong to the groups owning those locations but rather to their own matrilineal descent group's estates at other settlements. If descent group membership is more important for resources, support, and identities, then the local group may comprise conjugal families residing in their own settlement (i.e., uxorilocality or avunculocality). These conjugal family residential groups should not be confused with neolocality, which is not associated with unilineal descent. Interestingly, women in avunculocal societies never live with their matrilineal relatives; they grow up at their father's group location, postmaritally reside at their husband's group location, and are only with their matrilineal kin upon death (e.g., Keegan 2009).

Patrilineal household groups, centered around patrilineal parallel cousins, and much larger patrilineages and/or patriclans, entailing numerous and more biologically distant sets of patrilineal parallel cousins, are also exclusive corporate descent groups providing members with resources, mutual support, spiritual associations, ceremonial roles, shared emically intimate kin terms, and identities. The groups are reproduced through exogamy and patrilocality/virilocality. The leading hypothesis to explain patrilocality is a need to localize men's engendered division of labor and associated resources (Ember and Ember 1971; Fox 1967:77-85; Gough 1961:551-564). Virilocality, involving conjugal family residences at descent group locations, may be emphasized if membership and identity with the patrilineage/patriclan is more important than with household groups. Women remain members of their own group, where their loyalties, source of mutual support, and elders' control are focused despite being physically displaced. In many historic indigenous American cultures emphasizing patrilocality, women remained members of their own patrilineal groups. However, in other regions, and after European social engineering in the Americas, when patrilocality is combined with heightened gender inequality, married women's membership could be transferred to their husband's group. The patrilocally displaced women not sharing natal group memberships thus came to be under the exclusive authority of the men in their husband's natal group.

With bilateral descent, there are no descent groups. The largest corporate kin groups are at the scale of the household. Bilateral kindreds are not social groups but rather individuals' networks of bilateral kin that cross-cut household-scale groups. This strategy provides flexibility for either spouse to identify "kin," access resources, and even renegotiate membership in multiple households, which is why it is associated with resource uncertainty (e.g., Fox 1967:152-153; Gjessing 1975; Pasternak 1976). However, bilateral descent also creates divided loyalties and multiple sources of opportunities; exclusive descent groups do not (Fox 1967:152-153). Because there are no larger groups, some household groups may sponsor ceremonies or be a source for patron-client relations.

Under bilateral descent, household-scale groups could be corporate matrilineal household groups (reproduced with matrilocal residence), corporate patrilineal household groups (reproduced with patrilocal residence), or corporate bilocal residentialhousehold groups. The latter, when combined with the flexibility of bilateral descent strategies, are described as "houses" by LéviStrauss (1982:163-187). With bilocality, and unlike matrilocality 
and patrilocality, membership in a corporate household group is entirely negotiated through bilateral relationships, using either spouse's kindred relatives. Thus, through multiple postmarital residence strategies, the household core group can include brothers, sisters, cousins (parallel and/or cross), and potentially people who are not biologically related to other members. At stake in the negotiations is each married couple's, and their children's, access to household resources with which to make a living. In this case, membership to the corporate group is through residence; the residential and household groups are the same (residential-household group). If internal ranking is present, any member could succeed, although there tends to be patrilineal bias (e.g., Fox 1967; Keesing 1975:93-94). The leading hypotheses for bilocality involve small populations (Pasternak 1976:48), migration (Murdock 1949:204), resource shortages (Eggan 1966:58-64), and historic depopulation (Ember and Ember 1972).

Bilateral descent can also be associated with neolocality which, unlike uxorilocality, avunculocality, or virilocality, occurs where conjugal families are unassociated with corporate kin groups of any kind or scale. The conjugal family is dependent on nonkin to make a living (e.g., through private property, wage labor, or serfdom). Kindred relatives are unimportant for making a living; therefore, extended households are not formed, but bilateral relatives of either spouse can be used to strategically develop networks of support and alliances or even temporary work groups. Unlike household groups or residential-household groups, the neolocal conjugal family is not perpetuated across generations; it instead disintegrates when children establish new neolocal residences with their spouses (Fox 1967).

Corporate groups of different scales are thus created by manipulating gendered relationships. Each strategy provides access to resources, mutual assistance, spiritual associations, ceremonial organization, and identities. With unilineal descent, larger corporate descent groups are possible (i.e., lineages and clans). Important memberships are with the unilineal groups of origin or are transferred to those of husbands in some patrilineal strategies. With bilateral descent, corporate kin groups are restricted to the household scale, which can be associated with a variety of postmarital residence strategies. The focus now turns to the subject of group membership, postmortem location, and expected patterns for intracemetery biodistance for each of these strategies.

\section{Postmortem Location and Intracemetery Biodistance}

"Postmortem location"-in which cemeteries and with whom people are interred - differs by kinship strategy. The major patterns are represented in table 1. Expectations concerning biodistance are derived from these, considering group compositions. The modeled expectations assume multivariate analyses of morphological and/or metric cranial and/or dental traits. To simplify matters, the expectations are for adults only; societies often vary in placement of children and, sometimes, subadult burials within kin group cemeteries - perhaps be- cause they had not yet obtained the rights and duties recognized for full group membership (Carr 1995:184-185).

Cemeteries with definable boundaries at settlements indicate corporate groups. Saxe (1970) and Goldstein (1981) originally associated them with descent groups. However, Carr (1995:165) found that bounded cemeteries represent any form of corporate group, including household-scale kin groups, descent groups, or even non-kin-based sodalities (Carr 1995:182). Large communal descent group cemeteries indicate that membership in larger groups was important for affiliation, access to resources, and identity. On the other hand, cemeteries only associated with individual households suggest that household group membership was more important. If both large communal descent group and household-oriented cemeteries are present at a settlement, then the importance of these scales of corporate affiliation may have been negotiated. In any of these scenarios, however, the entire unilineal descent group should have been the exogamous unit. With bilateral descent, there may also be large town cemeteries (sodality cemeteries) or only those for each household-scale group. Combinations of these strategies may imply identity negotiation.

The following models on expected intracemetery phenotypic variation are meant to be synchronic. However, kinship strategies to form corporate groups change over time as gendered relationships are manipulated to alter membership criteria (e.g., Ensor 2013a). A pattern in postmortem location for one phase may differ in other phases, even within the same cemeteries. Therefore, bioarchaeological kinship analysis needs to consider a given cemetery phase by phase; otherwise phenotype distributions from multiple strategies may be inadvertently pooled. In doing so, patterns would be obscured and the diachronic trends that lend themselves to testing many hypotheses on change would not be revealed.

As a reminder, large descent groups (lineages and clans) cannot be biologically homogeneous, and postmarital residence does not predict postmortem location. We begin with large cemeteries for descent groups and for communities with bilateral descent that may also have communal cemeteries. Following these are the household-scale cemeteries with much smaller populations. The expected biodistance patterns are summarized in table 2.

\section{Matrilineal Descent Group Cemeteries}

Among the 28 ethnographic cultures in table 1, eight had exogamous matrilineal descent groups (matrilineages or matriclans). Seven of these had exclusive matrilineal descent group cemeteries. Among the Iroquois, Akan, Saramaka, Goajiro, Cibecue Western Apache, and Marshallese, the pattern was matrilineage or matriclan cemeteries for matrilineal members only. Men who lived matrilocally and/or women who lived avunculocally were returned to their matrilineal descent groups' cemeteries upon death. Among the Tlingit, there were large multigroup cemeteries, but each matrilineal descent group had its own location within them, and all individuals remained 
Table 2. Summary of phenotype biodistance expectations for cemetery populations and their interpretation

\begin{tabular}{|c|c|c|}
\hline Cemetery size, phenotypic distance & Phenotypic distance between adult sexes & Social organization \\
\hline \multicolumn{3}{|l|}{ Large cemeteries: } \\
\hline $\begin{array}{l}\text { Multiple statistical clusters of few adult } \\
\text { males and females, with high intercluster } \\
\text { distances }\end{array}$ & $\begin{array}{l}\text { No significant differences between } \\
\text { pooled males and pooled females }\end{array}$ & $\begin{array}{l}\text { Matrilineages or matriclans; patrilineages } \\
\text { or patriclans }\end{array}$ \\
\hline $\begin{array}{l}\text { Multiple statistical clusters of few adult } \\
\text { males, with high intercluster distances }\end{array}$ & $\begin{array}{l}\text { Significant differences between pooled } \\
\text { males and pooled females; greater } \\
\text { heterogeneity among females }\end{array}$ & $\begin{array}{l}\text { Patrilineages or patriclans, with transfer of wives' } \\
\text { membership to husbands' groups }\end{array}$ \\
\hline $\begin{array}{l}\text { Multiple statistical clusters of few adult } \\
\text { males and females, with a continuum of } \\
\text { intercluster distances (low to high) }\end{array}$ & $\begin{array}{l}\text { No significant differences between } \\
\text { pooled males and pooled females }\end{array}$ & $\begin{array}{l}\text { Bilateral descent combined with bilocality } \\
\text { or with neolocality }\end{array}$ \\
\hline $\begin{array}{l}\text { Multiple statistical clusters of few adult } \\
\text { females, with a continuum of intercluster } \\
\text { distances (low to high) }\end{array}$ & $\begin{array}{l}\text { Significant differences between pooled } \\
\text { males and pooled females; greater } \\
\text { heterogeneity among females }\end{array}$ & Bilateral descent combined with matrilocality \\
\hline $\begin{array}{l}\text { Multiple statistical clusters of few adult } \\
\text { males, with a continuum of intercluster } \\
\text { distances (low to high) }\end{array}$ & $\begin{array}{l}\text { Significant differences between pooled } \\
\text { males and pooled females; greater } \\
\text { heterogeneity among females }\end{array}$ & Bilateral descent combined with patrilocality \\
\hline \multicolumn{3}{|l|}{ Small household-scale cemeteries: } \\
\hline $\begin{array}{l}\text { Homogeneity among adult males and } \\
\text { females }\end{array}$ & $\begin{array}{l}\text { No significant differences between } \\
\text { pooled males and pooled females }\end{array}$ & $\begin{array}{l}\text { Matrilineal or patrilineal household group cemetery } \\
\text { within larger matrilineal or patrilineal descent } \\
\text { groups }\end{array}$ \\
\hline Homogeneity among adult males & $\begin{array}{l}\text { Significant differences between pooled } \\
\text { males and pooled females; greater } \\
\text { heterogeneity among females }\end{array}$ & $\begin{array}{l}\text { Patrilineal household group cemetery within larger } \\
\text { patrilineal descent group, with transfer of wives' } \\
\text { membership to husbands' groups }\end{array}$ \\
\hline $\begin{array}{l}\text { Homogeneity among some adult males } \\
\text { and females, with some heterogeneity }\end{array}$ & $\begin{array}{l}\text { No significant differences between } \\
\text { pooled males and pooled females }\end{array}$ & $\begin{array}{l}\text { Bilocal residential-household group under } \\
\text { bilateral descent }\end{array}$ \\
\hline Homogeneity among adult females & $\begin{array}{l}\text { Significant differences between pooled } \\
\text { males and pooled females; greater } \\
\text { heterogeneity among males }\end{array}$ & $\begin{array}{l}\text { Matrilocal household group cemetery under } \\
\text { bilateral descent }\end{array}$ \\
\hline Homogeneity among adult males & $\begin{array}{l}\text { Significant differences between pooled } \\
\text { males and pooled females; greater } \\
\text { heterogeneity among females }\end{array}$ & $\begin{array}{l}\text { Patrilocal household group cemetery under } \\
\text { bilateral descent }\end{array}$ \\
\hline
\end{tabular}

members of their matrilineal group despite matrilocality. The Ndyuka had lineage-owned cemeteries and multilineage cemeteries. Among those with the latter, an exception to the general pattern, there was no separation of graves by lineage. Nevertheless, in each of these examples, all members were returned to their matrilineal groups upon death for burial. Matrilineal postmortem location does not follow matrilocal postmarital residence.

As described and illustrated in figure 1, few members of a matrilineage or larger matriclan share close biological relationships. Within a matrilineal descent group, there should be multiple but biologically distant sets of biological siblings and their mothers. However, each set would be biologically distant from other sets within the matrilineal descent group; they cannot intermarry or produce offspring with one another due to descent group exogamy. Therefore, most individuals in a matrilineal cemetery should not be closely related biologically. Instead, there should be biodistance "clusters" representing numerous nonintermarrying mother-sibling groupings, although each should be distant from other intracemetery clusters. Figure $2 A$ illustrates a hypothetical multidimensional scaling (MDS) plot (e.g., see Kruskal and Wish 1978) for expected distances from a matrilineal descent group's ceme- tery. If the biodistance clusters are spatially clustered within the cemetery, greater significance to household group identity may be inferred. If not, then descent group identities can be interpreted as being more important.

The difference between these expectations for a matrilineal descent group cemetery and traditional assumptions have implications for intersubfield interpretation. For example, Schillaci and Stojanowski $(2002,2003)$ infer bilocality with a preference for patrilocality at Pueblo Bonito in Chaco Canyon based on intra- and intersex biodistances within two burial clusters and when pooling the clusters. Close phenetic relationships between few males and females in one cluster was interpreted as group endogamy (Schillaci and Stojanowski 2003:10). This conclusion involves two assumptions: (1) groups are biologically homogeneous, and (2) spouses are buried together. Alternatively, in light of the above discussion, the same pattern may indicate that siblings of both sexes of a descent group were buried together. They also observed greater biodistance between sexes in the other burial cluster and, based on a sexes-pooled comparison from both clusters, greater phenotypic variation among females. Assuming spouse coburial, this was interpreted as a preference for patrilocality. However, an MDS plot of interindividual biodistances for both burial clusters (Stojanowski and 


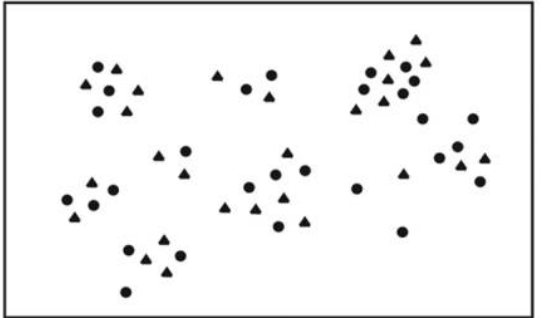

A

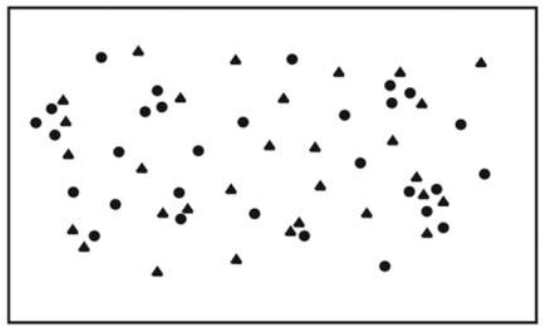

D

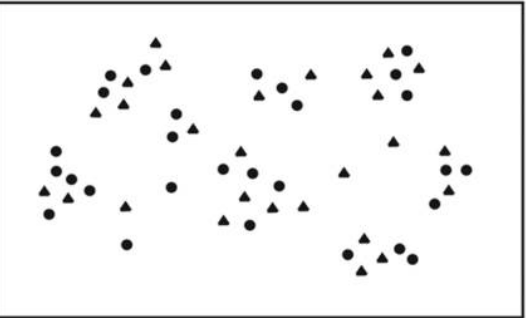

B

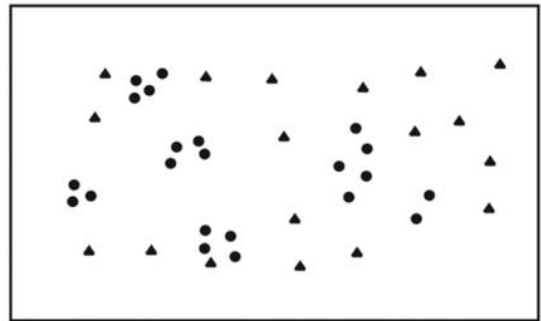

E

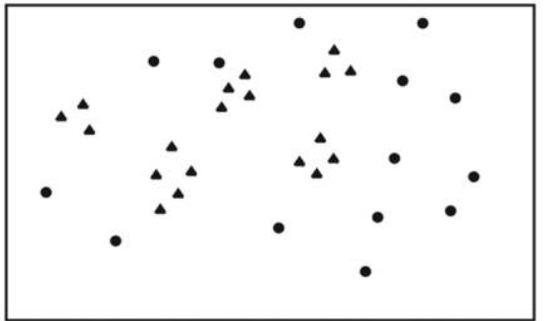

C

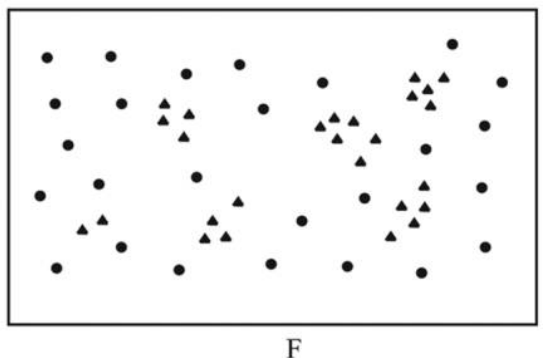

- Female $\triangle$ Male

Figure 2. Idealized expectations for multidimensional scaling plots of individuals in large cemeteries for a matrilineal descent group $(A)$, a patrilineal descent group without wives' transfer of membership $(B)$, a patrilineal descent group with wives' transferred membership $(C)$, multiple bilocal residential-household groups under bilateral descent $(D)$, multiple matrilocal residential groups under bilateral descent $(E)$, and multiple patrilocal residential groups under bilateral descent $(F)$.

Schillaci 2006, fig. 11) exhibits the clustering among few males and females with intercluster differences, described here as what would be expected for exogamous unilineal descent groups. Given archaeological data that support matrilocality (Ensor 2013a:65; Peregrine 2001; Peregrine and Ember 2002), in addition to a community pattern conforming to settlements for exogamous unilineal descent groups (Ensor 2013a:141-160), these biodistance results would alternatively be interpreted here as evidence for an exogamous matrilineal descent group.

\section{Patrilineal Descent Group Cemeteries}

There may be two alternate expectations concerning patrilineal group cemeteries. First, the deceased are returned to their patrilineage's or patriclan's cemetery regardless of postmarital residence. Women who live patrilocally after marriage would be returned to their own patrilineal group. Second, women's membership is transferred to the descent group of their husbands upon marriage, and spouses are buried in the same cemetery. In either case, the patrilineage or larger patriclan cemeteries should exhibit internal biological heterogeneity, not homogeneity.

Of the 28 cultures in table 1,13 had patrilineal descent groups. All possessed exclusive cemeteries for exogamous descent groups or multiple group cemeteries with distinct descent group areas. For six cultures, membership of women after marriage was unstated, including the Mongo with exogamous phratry (related patriclans) cemeteries; Igbo with patrilineage compound cemeteries; Nenets, Nivkh, and Samoyed with exogamous patriclan cemeteries; and Aymara with town cemeteries divided by patrilineal moieties.

Tallensi women remained members of their natal patriclan and were buried in their natal patriclan cemeteries. In these cases, because most members are not closely related biologically, the result should be heterogeneity: multiple clusters (each with biologically close individuals) yet with significant intercluster distances. Additionally, no significant differences should exist between pooled subsamples of men and women. Figure $2 B$ illustrates a hypothetical MDS plot for expected biodistance patterns from a patrilineal descent group's cemetery without transfers of women's membership.

The problem with these expectations is that matrilineal and patrilineal descent group organization cannot be distinguished through phenotypic traits when spouses do not transfer their memberships (fig. 2A, 2B). Mitochondrial DNA (mtDNA), on the other hand, would be well suited for distinguishing the two. With matrilineal descent, all women and men should exhibit minimal mtDNA distance despite the variation expected in phenotypic traits. With patrilineal descent groups, women and men should exhibit marked mtDNA variation, because mothers originate from multiple different patrilineal groups and typically will have distant biological relationships (see the discussion of Crow/Omaha marriage below).

Nevertheless, a potentially more common cross-cultural trend among societies with patrilineal descent is to transfer women's membership to the men's groups, which ultimately entails burial of postmaritally mobile wives in their husbands' patrilineage or 
patriclan cemeteries. Among the 13 cultures (table 1) with patrilineal descent groups, nearly half conformed to this second pattern: women transferred membership to their husbands' patrilineal groups and were buried in their husbands' patrilineage or patriclan cemetery. In this case, postmortem location matches postmarital residence. These cultures include the Shluh, Pashtun, Monguor, Serbs, Palestinians, and Korean rural lineages. Regarding variation in using patrilineage village cemeteries among the Pashtun, Barth (1965:39) states that "when she dies a wife is usually buried in the section of the village cemetery used by her husband's patriline; but usage in this respect varies in different localities. The return of the woman's body to her natal village is a recognized gesture of deference towards affines and matrilateral relations." Variation may also occur with the timing of membership transferal. Among Serbs having clan or village cemeteries with separate clan spaces, Filipovic (1982:49) states that "a woman becomes a part of her husband's rod only when she bears him a child. In . . Sumadija, for example, if a young woman dies before she has borne children she is not buried in the graveyard of her husband's clan but in that of her parents."

When women's memberships are transferred to their husbands' groups, the same phenotypic clusters of few biologically close members, with intercluster differences, should occur, although only among men. Adult females from multiple other descent groups should be even more heterogenous relative to males. And for the same reason, pooled adult females should exhibit significant differences from pooled adult males. Figure $2 C$ is an MDS plot showing what would be expected for a patrilineal descent group's cemetery with transfers of women's membership. Interpreting the transfer of women's membership also extends to an interpretation of significant gender inequality.

The expected biodistance clusters (of males and females, without women's membership transfers, or among males only, with women's membership transfers) may or may not conform to spatial clustering. If they do, it may illustrate that household group identity was emphasized alongside lineage or clan identity. If not, then identity with the higher-order lineage or clan can be interpreted as being more important than household group identity.

\section{Bilateral Descent and Large Cemeteries}

With bilateral descent and the lack of corporate descent groups above the household scale, residence determines postmortem location. For aggregated settlements considered now, non-kinbased sodalities may be the basis for larger corporate social functions and cemetery organization (e.g., town cemeteries), which again are determined by where one resides. Married men and women are expected to be buried in the same cemetery and possibly in close spatial proximity. Residential influence on postmortem location is illustrated in the seven cultures with bilateral descent (table 1).
Representing bilocality, the Lozi had cemeteries for multiple dispersed residential-houshold groups in which spouses were buried together. This is similar to a town cemetery but without aggregated settlement. One should keep in mind that, in cultures where bilateral descent is combined with bilocality, some married men and women remain in their natal residences while others do not. Nonbiologically related spouses can also be members, and more distant biological cousins may also negotiate their way into residential groups using bilateral kindred relations. Both within and among residential-household groups that share a cemetery, like among the Lozi, clusters of few close biological relations and a continuum of among-cluster distances should result. Men should exhibit a continuum of biodistance variation, as should women, but pooled adult males and females should not differ significantly (fig. 2D). Because bilocality and bilateral descent tend to have patrilocal biases (e.g., Keesing 1975:93-94; Fox 1967), there may be slightly greater similarities among men than women.

Even with unilocality, residence determines postmortem location under bilateral descent. Nine cultures in table 1 practiced matrilocality. Among these, only the bilateral Cuna buried married men with their wives. This example again illustrates how residence determines postmortem location under bilateral descent. When bilateral descent is combined with matrilocality, men from multiple different groups will be buried in the same cemeteries as their wives. In this case, clusters of close biological distances should be among few women only, because their brothers are buried in their wives' cemeteries. Because they originate from different groups, males - the recruited husbands - should display marked variation and, if pooled, should be significantly different from females (fig. 2E).

Among the patrilocal Bella Coola, Tongan commoners of Pangai, and Tzeltal Maya experiencing a shift from patrilineage organization to bilateral descent, married men and womenalong with deceased unmarried children - were buried together in village cemeteries, and patrilocal residence determined postmortem location. With practices like that, intracemetery biodistance analyses should have results opposite to those for matrilocality under bilateral descent: clusters should be among few close biologically related men only (because their sisters would be buried in their husbands' cemeteries). Because wives originate from multiple other groups, they should be heterogeneous and, when pooling by sex, significantly different from males (fig. $2 F$ ).

Neolocality, which is always associated with bilateral descent, also governs postmortem placement. Among the Highland Scotts, neolocal conjugal families had plots in village cemeteries. However, neolocal conjugal families among the Greek refugee community used town cemeteries without conjugal family plots. In the case of village cemeteries, biodistance clusters of few individuals should occur, yet with the same continuum expected for bilocality. For larger cemeteries serving urban populations, there should be great distances among the numerous, nonbiologically related small clusters. These results may or may not conform to spatial clusters in burials. 


\section{Small Household-Scale Cemeteries}

In many cultures, cemeteries were established for householdscale groups. In these cases, each household - consisting of the physical dwellings, support structures, and communal spaceswas also associated with a small cemetery. This may occur with widely dispersed farmsteads or even in villages lacking communal cemeteries. Such cemeteries signify that, whether larger corporate groups exist or not, the household-scale groups were more important for identity. Household-scale cemeteries may even accompany larger communal cemeteries for corporate descent groups, indicating negotiation of the importance of identities between household groups and their larger descent groups. Household-scale cemeteries require some modifications to the expectations described above, because - unlike lineage- or clanscale cemeteries - they are small and include only people having close biological relationships (i.e., only members of an extended family).

Cemeteries for matrilineal household groups within matrilineages or matriclans should include siblings of both sexes, mothers and their siblings of both sexes, and matrilineal parallel cousins of both sexes. More distant descent group members would be buried in their matrilineal household group cemeteries. The results of a multivariate biodistance analysis should demonstrate low variation among all individuals with no significant differences between pooled male and female subsamples. In other words, unlike matrilineage- and matriclan-scale cemeteries, intracemetery homogeneity among members should be expected in matrilineal household-scale cemeteries.

Cemeteries for patrilineal household groups within patrilineages or patriclans and without the transferring of married women's membership would be comprised of patrilineally related siblings of both sexes, fathers and their siblings of both sexes, and patrilineal parallel cousins of both sexes. Excluded would be more biologically distant members of the same patrilineal descent group if each patrilineal household group has its own small cemetery. An intracemetery multivariate biodistance analysis should result in low variation among all individuals and without significant differences between pooled males and females: the same results for matrilineal household group cemeteries within matrilineal descent groups.

There is a different expectation if wives' membership is transferred to their husbands' groups. All patrilineally related men of the group would still be interred together: male siblings, their fathers and fathers' brothers, and patrilineal parallel male cousins. Excluded would be married sisters, patrilineal parallel female cousins, and patrilineal aunts (fathers' sisters). Replacing these women would be the wives who originated from other patrilineal groups. The household-scale cemetery population should exhibit low distances among all males, significant differences between pooled males and females, and greater heterogeneity among females.

Cemetery populations for individual bilocal residentialhousehold groups under bilateral descent could include some siblings of either sex, mothers and fathers (and some of their siblings of either sex), some patrilateral and/or matrilateral parallel and/or cross cousins of either sex, and some nonbiologically related wives and/or husbands. Despite the wide variation in potential bilocal residential-household group compositions, the expected pattern is simple. Most males and females should exhibit low biodistances. However, some males and some females should exhibit greater distances and greater heterogeneity.

Cemetery populations for matrilocal residential groups under bilateral descent would include the matrilineally related females (sisters, their mothers and their sisters, and matrilineal parallel female cousins), all with close biological affinities. However, because postmortem location conforms with residential group membership under bilateral descent, the cemetery should also contain nonbiologically related males (husbands from other groups) who should exhibit greater distances from the females when both are pooled and exhibit greater heterogeneity.

Cemeteries for patrilocal residential groups under bilateral descent should include males with close biological affinities (brothers, their fathers and their brothers, and patrilineal parallel male cousins). Surrounding this core, outliers would include inmarrying females who originate from different multiple groups; they would exhibit notable heterogeneity and significant differences relative to the males.

As demonstrated, modeling of biodistance within cemeteries is far more complicated than previously assumed. Nevertheless, distinctive models for intracemetery biodistance can be produced for different kinship strategies when considering associated patterns in postmortem location and group compositions. These considerations allow more precise and betterinformed interpretations on social organizations and their significance to gender dynamics and identities. However, the models in this section do not consider the effects of marriage. Phenotypes themselves are the products of marriages and inheritance; they are a biocultural phenomenon. To understand phenotype frequency distributions within and across groups, and hence within and across cemeteries and settlements, marriage systems must be considered.

\section{Marriage Systems: Gene Flow and Phenotype Distributions}

Marriage rules prohibit random mating and thus channel patterns in gene flow among corporate groups. Because marriage systems govern the distribution of alleles, they are cultural practices guiding the creation of phenotypes and their frequencies within and among populations. Within populations, marriage systems may prevent the exchange of alleles among some groups while encouraging their distribution among others. Certain marriage systems create biological linkages among only a few members of corporate kin groups in a way that prevents other biological relationships within and across groups from developing. The three major categories of marriage systems introduced by Lévi-Strauss $(1965,1969)$ are elementary alliances, 
complex alliances, and Crow/Omaha alliances. The purpose of any marital system is to socially reproduce the given social organization while ensuring marriages for the perpetuation of the groups through reciprocal or competitive "exchanges." However, each system directs gene flow among groups in different ways.

All unilineal groups must maintain preferences, if not de jure rules, for exogamy. Given exogamy, there should be little gene flow among members of matrilineal or patrilineal household groups, lineages, or clans. The exogamy associated with these forms of social organization compels gene flow with other groups. Two marriage systems are associated with unilineal descent groups: elementary (with two major forms) and Crow/ Omaha.

With elementary alliances, each unilineal descent group has a specific marriage pool - another unilineal descent group with which it "exchanges" sons if matrilineal or daughters if patrilineal. In restricted elementary systems, only two groups intermarry; groups A and B always "exchange" members, creating reciprocal alliances between groups. The reciprocal alliances enable access to resources among the two groups' members and provide a source of social security (e.g., Fox 1967; Lévi-Strauss 1969). Likewise, groups C and D always intermarry to form reciprocal alliances. In this case, all members of descent groups $\mathrm{A}$ and $\mathrm{B}$ should exhibit close biological relatedness among both males and females, and all members of descent groups C and D should exhibit close biological relatedness among both males and females, but the pooled males and females of the A-B groups should exhibit greater biodistance from the pooled C-D groups. A more broadly scaled analysis should result in pairs of phenotypically close descent group cemeteries with significant differences among the multiple pairs.

In generalized elementary systems, and assuming four descent groups for this example, group A "gives" spouses only to group B, which "gives" spouses only to group C, which "gives" spouses only to group D, which "gives" spouses only to group A (Fox 1967; Lévi-Strauss 1969). The exchanges are another form of reciprocity, but they link many more groups throughout the society. Gene flow is therefore circular: from A to B, B to C, C to D, and D to A. From the time this system of reciprocal alliances is adopted, it should take several generations for gene flow to lower the intergroup genetic distances, creating homogeneity both within and among the descent group members. On a broader scale, all cemetery populations (males and females) should exhibit greater homogeneity over time.

There are no descent group-oriented rules in complex marital alliances. This system is associated with bilateral descent, which lacks descent groups. Marriage rules are individualbased taboos on marrying close consanguineal bilateral relatives. The taboos may pertain only to biological parents and siblings, or they may be extended to cousins. There are no prescribed marriage pools; each household must compete to attract marital alliances for members to ensure perpetuation of the corporate group (Fox 1967; Lévi-Strauss 1969). The result is a network of maritally based social alliances cross-cutting house- hold groups within and among settlements. If bilocal and lacking a prohibition against cousin marriage, then members of the same natal residential-household group could potentially intermarry to retain inheritance rights among group members. For this reason, gene flow will occur among some members within household groups but not among all. Biodistance clustering should therefore involve individuals across multiple household cemeteries within and across settlements. Unilineal household groups' exogamous preferences may be added, resulting in the expectations for matrilineal or patrilineal household groups under bilateral descent. If there is a preference for village endogamy, usually to keep access to resources among groups within the settlement, then biodistance clustering within and among a settlement's cemetery populations can be expected, although there should be greater differences between settlement populations. If there is a preference for village exogamy, usually to establish alliances with other settlements as a form of social security, then biodistance clustering across settlements can be expected.

Crow/Omaha marital alliances have characteristics of both elementary and complex marriage systems (Fox 1967). In addition to descent group-based rules, there are also individualfocused rules. Marriages are among members of different exogamous clans (or lineages in the absence of clans). The matrilineal version is the Crow system. In addition to matriclan exogamy (despite distant biological relations among most clanmates), each individual is also prohibited from marrying any member of their father's matriclan (despite most of them having distant biological relationships to the father; Fox 1967; LéviStrauss 1965). An additional prohibition may be extended to all members of mother's father's matriclan (despite most in that clan having distant biological relationships to the mother's father). In the patrilineal Omaha version, the rules include patriclan exogamy and a prohibition against marrying members of mother's patriclan, sometimes extended to father's mother's patriclan (even though most members of these clans have distant biological relationships; Fox 1967; Lévi-Strauss 1965). Empirical data on marriages indicate that the Omaha proper greatly adhered to these prohibitions in the nineteenth century (Ensor 2003). Crow/Omaha prohibitions are a social strategy to more evenly distribute marriage alliances (and, by consequence, gene flow) among more numerous clans.

Taking a closer look at the Crow/Omaha systems, different siblingships within a clan receive alleles and spread them among different sets of clans. In the Crow system, a set of siblings receives alleles from few members of their own clan (through their mother and her mother), from their father's clan (through their father and his mother), and from their mother's father's clan (through their mother's father and his mother). The same siblings may find spouses in any one of the additional clans that are not prohibited. Brothers will pass alleles to their children belonging to, and eventually buried with, other clans. Interclan biodistance clustering is created in this way. However, different siblingships within a given clan have different fathers' clans and different mothers' fathers' clans, which means that each clan as a 
whole has biological connections with all others, which is indicated by both intra- and interclan biodistance clustering.

Table 3 illustrates how this clustering occurs in a hypothetical society comprised of six exogamous matriclans. Clan A has five sets of siblings, each with fathers and mother's fathers belonging to different clans. For sibling set 1 of clan A, their father belongs to clan D and their mother's father belongs to clan F. Children of the women of sibling set 1 will obtain alleles from their mothers in clan A, which is also their clan, and will obtain alleles from their mothers' husbands who must come from clan B, C, or E. The men of sibling set 1 will pass alleles to their children, who belong to their wive's clans (either B, C, or $\mathrm{E})$, and those children will also receive alleles from their mother in their own clan. However, other sibling sets in clan A have received alleles from members of different clans, because they have different fathers and mothers' fathers. Thus they have different permitted clans to which they may pass alleles through the men. This arrangement is yet another way to explain how the Crow marriage system perpetuates intraclan heterogeneity and biodistance clustering among members of different clans.

An example of how these expectations are matched in a bioarchaeological study of a prehistoric society can be illustrated with Howell and Kintigh's (1996) biodistance results from multiple cemeteries at the ancestral Zuni settlement of Hawikku. From their maps and descriptions, the pueblo consisted of five large room blocks and 10 cemeteries with a total of 873 identified burials. To test whether the cemeteries were for lineages or clans, they conducted a multivariate cluster analysis on 54 individuals having sufficient numbers of traits recorded from seven cemeteries. Six trait “clusters," labeled A through F, were identified. Some cemeteries were dominated by one trait cluster, suggesting close biological relatedness; there were also several instances of individuals interred near one another who shared the same trait clusters, suggesting "family" locations within cemeteries. Although demonstrating that these results were nonrandom, each trait cluster was found in multiple cemeteries. To illustrate, trait cluster A was shared by four individuals in cemetery 1 , five in cemetery 3 , and seven in cemetery 9. Because they assumed each descent group should be relatively homogeneous, these results contradicted their expectations for descent group cemeteries, leading them to consider disruptive factors (spouses buried together, adoption of nonbiological kin, breaking prescriptions on burial locations, merging of different kin groups' cemetery spaces over time, and fissioning). However, their results are those that would be expected on the basis of the assumptions herein for multiple exogamous descent groups engaged in a Crow/Omaha marriage system.

Hawikku was a large settlement that apparently had intermarrying exogamous descent groups. However, it may be more common cross-culturally, or for certain periods without such aggregation, for descent groups to have individual settlements distributed across the landscape. A broad perspective is therefore required to identify marriage systems. Data from one cemetery population or comparisons of two or few cemeteries within a single settlement cannot adequately reflect the expected phenotype distributions created by marriage systems. If bioarchaeologists are restricted to one site for analysis, when socially constructed kinship relations and marriage transcend settlements, the result is partial glimpses of a larger system of relationships.

Table 3. Hypothetical illustration of how sibling sets share and spread alleles across clans in a Crow marriage system

\begin{tabular}{|c|c|c|c|c|c|c|}
\hline Clan A sibling sets & Clan B & Clan C & Clan D & Clan E & Clan F & Marriage prohibition implications \\
\hline 1: men & $\ldots$ & $\ldots$ & $\mathrm{F}$ & $\ldots$ & MF & $\begin{array}{l}\text { Children belonging to (and buried with) clan B, C, } \\
\text { or E will obtain alleles from clan A members. }\end{array}$ \\
\hline 1: women & $\ldots$ & $\ldots$ & $\mathrm{F}$ & $\ldots$ & MF & $\begin{array}{l}\text { Clan A children will obtain alleles from a husband } \\
\text { belonging to (and buried with) clan B, C, or E. }\end{array}$ \\
\hline 2: men & MF & $\mathrm{F}$ & $\cdots$ & $\cdots$ & $\ldots$ & $\begin{array}{l}\text { Children belonging to (and buried with) clan } \mathrm{D}, \mathrm{E} \\
\text { or F will obtain alleles from clan A members. }\end{array}$ \\
\hline 2: women & MF & $\mathrm{F}$ & $\ldots$ & $\ldots$ & $\ldots$ & $\begin{array}{l}\text { Clan A children will obtain alleles from a husband } \\
\text { belonging to (and buried with) clan } \mathrm{D}, \mathrm{E} \text {, or } \mathrm{F} \text {. }\end{array}$ \\
\hline 3: men & $\mathrm{F}$ & $\ldots$ & MF & $\ldots$ & $\ldots$ & $\begin{array}{l}\text { Children belonging to (and buried with) clan C, E, } \\
\text { or F will obtain alleles from clan A members. }\end{array}$ \\
\hline 3: women & $\mathrm{F}$ & $\ldots$ & MF & $\ldots$ & $\ldots$ & $\begin{array}{l}\text { Clan A children will obtain alleles from a husband } \\
\text { belonging to (and buried with) clan C, E, or F. }\end{array}$ \\
\hline 4: men & $\cdots$ & MF & $\ldots$ & $\mathrm{F}$ & $\ldots$ & $\begin{array}{l}\text { Children belonging to (and buried with) clan B, D, } \\
\text { or F will obtain alleles from clan A members. }\end{array}$ \\
\hline 4: women & $\ldots$ & MF & $\ldots$ & $\mathrm{F}$ & $\ldots$ & $\begin{array}{l}\text { Clan A children will obtain alleles from a husband } \\
\text { belonging to (and buried with) clan B, D, or F. }\end{array}$ \\
\hline 5: men & $\cdots$ & $\cdots$ & $\cdots$ & $\mathrm{F}$ & MF & $\begin{array}{l}\text { Children belonging to (and buried with) clan B, C, } \\
\text { or D will obtain alleles from clan A members. }\end{array}$ \\
\hline 5: women & $\ldots$ & $\ldots$ & $\ldots$ & $\mathrm{F}$ & MF & $\begin{array}{l}\text { Clan A children will obtain alleles from a husband } \\
\text { belonging to (and buried with) clan B, C, or D. }\end{array}$ \\
\hline
\end{tabular}

Note. Existing gene flow among clan A members and members of other clans is indicated by F (father's clan) and MF (mother's father's clan), in which siblings cannot seek spouses. Marriages are permitted with members of other clans, enabling new, additional gene flow across clans. 
Although it is not the cemetery-by-cemetery analyses within and across sites at a regional scale that we are calling for, one example of a regional perspective that does consider marriage practices is by Stefan (1999); he looked at craniometric data from different tribal regions across Rapa Nui. Given homogeneity across tribal populations, lineage exogamy within and across tribes (for commoners) was interpreted. However, when considering the lack of significant differences between sexes, Stefan assumes that spouses were buried together, leading to the interpretation of notable levels of lineage endogamy. If endogamous, then lineage organization would break down. As an alternative, we suggest that the internal homogeneity across areas was due to Crow-Omaha-like lineage prohibitions compelling each to form marital alliances among numerous lineages; furthermore, the homogeneity among sexes within tribal areas likely had more to do with centuries of exogamous gene flow and the return of individuals to their natal locations for burial than with lineage endogamy.

Some caution is necessary when interpreting changing phenotype frequencies and distributions. Like intracemetery biodistance research, marriage systems should also be examined chronologically on a phase-by-phase basis to avoid the compiling of phenotype distributions caused by changing marriage practices. Moreover, a change in marriage systems should lead to changes in phenotype distributions, which may in turn be confused for population migrations or replacements interpreted through culture historical perspectives; the latter may serve to inflame controversies over dominant ethnic groups' versus indigenous populations' claims on ancestral lands and territories. It is therefore important to acknowledge that changing marriage systems influence population phenotype frequencies and distributions, which can also open doors to new research on old interpretations.

This section provides only a brief sketch of marital systems. Nevertheless, the overview of these major categories should be sufficient to illustrate their role in regulating gene flow and phenotype distributions within and among kin groups. Their study seems a necessary but largely unexplored area in bioarchaeological research on kinship but could aid in the interpretation and understanding of prehistoric kinship while expanding the scope of research.

\section{Prospects}

The ethnologically derived models of kinship behavior and social organization described here have far more complex implications for phenotype distributions than is commonly assumed in previous bioarchaeological literature. The major takeaway points are that kinship is not the subject of biological relatedness, postmortem location does not always correspond to postmarital residence and is instead governed by group membership, descent groups are not homogeneous, and marriage systems are essential for understanding phenotype distributions. Alternative biodistance models were introduced to better distinguish different unilineal descent groups, bilat- eral descent, and the effects of marriage systems. A more sophisticated bioarchaeology of kinship is within reach to apply the advanced model-free and model-bound quantitative methods already in use. Once interpretive models are reconceptualized, bioarchaeologists will be in a stronger position to communicate more effectively across subfields engaged in kinship analyses and to test other subfields' interpretations and generalizing hypotheses on kinship. Moreover, bioarchaeologists alone are forced to examine the interface between biological data and socially constructed kin groups - a relationship that ethnologists, archaeologists, and linguists can conveniently avoid. As this essay emphasizes, different kinship and marriage strategies result in variable biological interconnectedness within and across social groups. As such, bioarchaeology should be central to discussions on the culturally constructed relationships between kinship strategies and biology.

By interpreting the ways that past humans manipulated social relationships to form groups, how genders were influenced by those strategies, and how identities were negotiated, bioarchaeology has a large contributive role to play in anthropology. The challenges are many when considering the complex implications on phenotype distributions described here. Nevertheless, it is most likely that the subfield's methodological and statistical expertise can be applied to address kinship in a more sophisticated manner, creating opportunities for contributions to broader anthropological understandings of variable and changing human social life.

\section{Acknowledgments}

We thank the anonymous reviewers for helpful comments and hope our resulting revisions better relate the kinship concepts herein to the targeted audience of bioarchaeologists. Special thanks go to Christiane Cunnar and Lisa Klopfer, who facilitated access to the eHRAF database. The article also benefitted from the current perspectives presented in the "Bioarchaeological Approaches to Kinship: Bridging Biology, Social Relatedness, and Theory" symposium at the 79th Annual Meeting of the Society for American Archaeology, for which thanks go to the organizers (Kent Johnson and Kathleen Paul) and all of the participants.

\section{APPENDIX}

\section{Glossary}

affine: A relative through marriage.

avunculocality: A postmarital residence practice whereby a married couple resides with the matrilineal descent group of the husband's matrilineal uncle.

bilateral descent: Descent reckoning placing emphasis on mother's and father's sides, including all those descended from mother's mother and father (and their siblings) and all those descended from father's mother and father (and their siblings). The basis for individual kindreds. Bilateral descent 
crosses kin groups, thus dividing individuals' loyalties while, at the same time, providing negotiable opportunities for support. The major form of descent in Western cultures that ideologically emphasize individuals and biological relatedness but which does not conform with the social and biological makeup of unilineal descent groups (lineages or clans).

bilocal residential-household group: An extended residential group - usually a corporate property-owninggroup - formed through the bilocality of its members. Unlike corporate groups in matrilineal and patrilineal societies, the residential group and the corporate group are the same.

bilocality: A postmarital residence practice whereby each married couple negotiates whether to reside at the wife's or the husband's natal residence, or potentially another residence via bilateral descent.

clan: Not a biological collection of kin. A large exogamous unilineal descent group (with potentially hundreds or even thousands of members) whereby members trace descent with one another matrilineally (a matriclan) or patrilineally (a patriclan) back to known or mythical founding ancestors, thus excluding most of each individual member's biological kindred relatives. Societies differ in corporate clan functions: in some they collectively own property, in most they sponsor ceremonies, and in all they provide a large group for mutual support from and obligations to members (regardless of biological distance) that may not extend to biologically close members of other clans. Clans commonly comprise multiple subclan lineages.

complex marriage: An individual-based marriage system (as opposed to a group-based marriage system) with one rule prohibiting marriages among biologically "close kin" (variably defined by cultures) associated with bilateral descent, thus spreading marriages - and biological relations of children - across groups potentially randomly or, depending on customary preferences, within or across settlements, classes, ethnicities, or levels of educational attainment. The major form of marriage in Western cultures that ideologically emphasize individuals and biological relatedness.

conjugal family: At a minimum, a mother and her child, but usually including two or more parents and children. Preferred over "nuclear family" to avoid the false Western connotation of a universal biological "building block" of kinship.

Crow marriage: A matrilineal descent group-based marriage system whereby individuals and their siblings are prohibited from marrying anyone in their own exogamous matriclan (even though most members are biologically distant), their father's matriclan (even though most members are biologically distant to father), and in some societies their mother's father's matriclan (even though most members are biologically distant to mother's father). Marriages with members of other clans are permissible (regardless of biological distance to their members). The proscriptions disperse marriages - and gene flow_-across numerous clans, inhibiting intense gene flow between two or few clans. In the absence of clans, the same rules may apply to exogamous matrilineages.

elementary marriage: A descent group-based marriage system (for matrilineal or patrilineal descent groups) whereby individuals must marry someone in another prescribed descent group. In the restricted form, two groups "exchange" people in marriage (e.g., $\mathrm{A} \leftrightarrow \mathrm{B}, \mathrm{C} \leftrightarrow \mathrm{D}$ ), resulting in close biological relatedness between the pair of "exchanging" groups but with no gene flow to additional groups. In the generalized form, a group always "gives" spouses to a specified second group but always "receives" spouses from another specified group (e.g., $\mathrm{A} \rightarrow \mathrm{B} \rightarrow \mathrm{C} \rightarrow \mathrm{D} \rightarrow \mathrm{A}$ ), resulting in gene flow across all groups.

exogamy: A rule or preference for marriage outside one's social group (however defined). The opposite is endogamy (rule or preference for marriage within one's social group). In the case of unilineal descent groups, the groups must be exogamous to maintain the principle of unilineal descent group membership. In the case of bilateral descent and complex marriage, exogamy or endogamy may be preferences.

family: A vague, nonspecific term with numerous variable meanings within and across cultures and social sciences. Sometimes but not necessarily conceptualized as socially based, biologically based, group based, and/or network based.

household group: A corporate property-owning extended family with exclusive membership, herein emphasizing those based on unilineal descent. Not to be confused with a residential group.

kin: A nonspecific, generalized, and variably meaning reference to social and/or biological relations.

kin group: A nonspecific, generalized, and variably meaning reference to social groups (having an identifiable membership) organized through any of the numerous possible principles.

kindred: Not a group but rather a specific reference to an individual's bilateral and consanguineal (biologically related) network of kin. In some societies, affines may be customarily included. With the exception of siblings, different individuals have different kindreds, regardless of whether they belong to the same social groups. In societies emphasizing bilateral descent, kindred relations may be used to form temporary work groups. Recognized kindreds are as large as they are useful; in Western societies having "genealogical amnesia," they are usually comparatively small networks, because kin are not the most important basis for making a living, thus requiring genealogical research on bilateral/ biological relations to identify more, but previously unrecognized, "kin."

kinship: As defined by Murdock (1949), the general subject matter of relationships, be they social and/or biological.

lineage: Not a collection of biological kin. A unilineal descent group (with potentially hundreds of members) whereby members trace descent with one another matrilineally (a matri- 
lineage) or patrilineally (a patrilineage) back to founding ancestors (known or mythical), thus excluding most of each member's biological kindred relatives. Societies differ in corporate lineage functions: in most, they collectively own property, and in nearly all, they have exclusive ceremonies and provide a large group for mutual support from and obligations to members (regardless of biological distance) that may not extend to biologically close members of other lineages. Unless nested within clans, the lineages are exogamous to preserve the unilineal principle of descent-based membership. Lineages commonly comprise multiple unilineal household groups.

matriclan: A clan based on matrilineal descent principles for exclusive membership; see clan.

matrilineage: A lineage based on matrilineal descent principles for exclusive membership; see lineage.

matrilineal descent: The practice and ideology of tracing descent through mothers only, thus excluding fathers and all others from one's line of descent and therefore excluding the majority of biological relationships from one's line of descent.

matrilineal descent group: A unilineal descent group (see lineage and clan) with exclusive membership dictated by the principle of matrilineal descent, thus excluding most of each members' biological kin.

matrilineal household group: A corporate group based on matrilineal descent principles for exclusive membership; see household group.

matrilocal residential group: A coresiding group of matrilineally related women and children joined by their husbands who are displaced but belong to their own matrilineal household groups (unless men transfer their membership upon marriage) resulting from matrilocality; see residential group.

matrilocality: A postmarital residence practice defined by a married couple's residence with the wife's mother. "Uxorilocality," specifically referencing residence with the wife's sisters, is subsumed but may exist in the absence of matrilocality.

neolocality: A postmarital residence practice defined by a married couple's establishment of a new home away from either spouses' kin. Unlike other kin groups, a nonperpetuating group that dissolves as children move away and form new neolocal residences. Commonly associated with a dependence on nonkin for making a living (e.g., wage labor or private property) and thus expanding with commercial globalization. The major form of residence emphasized in Western cultures, possibly giving rise to naturalizing and universalizing Western notions of what constitutes "family" and an atomizing view of kinship as biological relatedness.

Omaha marriage: A patrilineal descent group-based marriage system whereby individuals and their siblings are prohibited from marrying anyone in their own exogamous patriclan (even though most members are biologically distant), their mother's patriclan (even though most members are biologically distant to mother), and in some societies their father's mother's patriclan (even though most members are biologically distant to father's mother). Marriages with members of other clans are permissible (regardless of biological distance to their members). The proscriptions disperse marriages - and gene flow - across numerous clans, inhibiting intense gene flow between two or few clans. In the absence of clans, the same rules may apply to exogamous patrilineages.

patriclan: A clan based on patrilineal descent principles for exclusive membership; see clan.

patrilineage: A lineage based on patrilineal descent principles for exclusive membership; see lineage.

patrilineal descent: The practice and ideology of tracing descent through fathers only, thus excluding mothers and all others from one's line of descent and therefore excluding the majority of biological relationships from one's line of descent.

patrilineal descent group: A unilineal descent group (see lineage and clan) with exclusive membership dictated by the principle of patrilineal descent, thus excluding most of each members' biological kin.

patrilineal household group: A corporate group based on patrilineal descent principles for exclusive membership; see household group.

patrilocal residential group: A coresiding group of patrilineally related men and children joined by their wives who are displaced but belong to their own patrilineal household groups (unless women transfer their membership upon marriage) resulting from patrilocality. See residential group. patrilocality: A postmarital residence practice defined by a married couple's residence with the husband's father. "Virilocality," specifically referencing residence with the husband's brothers, is subsumed but may exist in the absence of patrilocality.

residential group: A coresiding group of people, including affines recruited through marriage who, despite dislocation, remain members of their own household group (unless they transfer membership upon marriage). The primary function of the residential group is to reproduce and perpetuate the corporate household group.

sodality: A group with any social function whose membership is not based on kinship relations.

\section{Comments}

\section{Patrick McConvell}

School of Language Studies, Australian National University, Canberra, Australian Capital Territory 0200, Australia (patrick.mcconvell@anu.edu.au).6I 17

A strength of Ensor, Irish, and Keegan's article lies in integrating archaeological and bioarchaeological approaches to kin- 
ship structures of localities, such as settlements and cemeteries, with the ethnographic findings of sociocultural anthropology on types of social organization, especially descent groups. This could contribute toward a robust, coherent practice among anthropological subdisciplines. Also useful is the authors' critique of the tradition in bioarchaeology that perceives kinship as directly mapping onto biology — a position long rejected by sociocultural anthropology. They hope to influence bioarchaeology toward an understanding of the synergy of culture and biology in kinship, which would benefit anthropology as a whole.

One shortcoming in this article is the lack of explanation of phenetic taximetrics as used by the bioarchaeologists and how it relates to molecular genomics (apparently not employed by the authors). While the authors acknowledge that descent group organization cannot always be determined through phenotypic traits, they touch only briefly on mitochondrial DNA, which could be used to distinguish between matrilineal and patrilineal descent groups. This issue deserves more coverage; as a key tool in the categorization of kinship groupings, it would facilitate successful pursuit of the research program outlined.

The contribution of bioarchaeology to providing results in diachronic kinship is emphasized, but I detect a corresponding devaluing of the contributions of ethnohistory and linguistic prehistory. In discussing the origins of descent groups, Ensor (2013a:126) says that there is insufficient longitudinal data and that "only" archaeology can provide evidence. In this article, the primacy and necessity of archaeology and bioarchaeology for diachronic kinship research is asserted because only they "have access to data that date to the prehistoric periods in question." This is only so because the authors rule out a priori the robust results available from linguistic reconstruction. There are hints of some serious issues in the background here, suggested by the ironic quotation marks around "reconstruct" in "approaches to ethnographic kin-term semantics attempt to 'reconstruct' prehistoric kinship with interpretation guided by phylogenetic models and historical particularism," as if the concept of reconstruction itself is being challenged. The references to phylogenetic models and historical particularism also have a negative tone.

I have difficulty reconciling the equation in this article between Crow terminology and matrilineality and Omaha terminology and patrilineality. This is indeed the alignment in the majority of cases, but it is necessary to separate the skewing rule from the descent lines, as it is well known that there are disjunctions here (e.g., the lack of close fit in results between skewed cousin terms and lineality in the Ethnographic Atlas Crosstabulation; CSAC 2017). This indicates that the two patterns may operate independently or that there is a time lag between switch in one and switch in the other. This is not an unnecessary complication that needs to be simplified away but a key element in following how and why transitions occur.

This impacts on the situation of Muskogean, especially Creek, the main group analyzed by Ensor (2013a). Muskogean and Creek had unusually high levels of variation in social organization in different places and different eras, noted in the ethnohistorical studies. This includes switching between Crow (matrilineal) and Omaha (patrilineal) systems, found in some other American indigenous regions, and between the skewing systems and symmetrical exchange and cognatic systems at other times and places. This could provide a laboratory for how these variations switch on and off and possible causative factors, extensively discussed in the anthropological literature.

The majority of those who have studied Creek and Muskogean more generally propose that the original system was Crow but that variations appeared in the turbulent history of forced movement and contact in the nineteenth century (e.g., Eggan 1937). The deeper history through archaeology and bioarchaeology tends to point to a much longer suite of transitions and parallel existence of different forms of social organization. This could be pursued with comparison of these findings with those of ethnohistory and linguistic prehistory, but these authors do not favor this method. Urban and Jackson (2004) review changes in kinship and social organization going back to the foundation of the Creek Confederacy and the formation of towns, in part by immigration of mixed ethnic groups in the early nineteenth century, and suggest such diversity may have been older than this. They challenge the view of Eggan and others about a dominant and original Crow system and point out that some groups had apparently discordant lineality and skewing systems (e.g., Yuchi with Omaha skewing and matrilineality; Urban and Jackson 2004:701). Such combinations are problematic for the kind of simplified framework proposed for bioarchaeology in this article.

Historical reconstruction of forms of social organization through linguistic prehistory, contrary to the approach of this article and Ensor elsewhere, is an important source of evidence. Reconstruction does not mean only of a single fixed system at a particular time and place. I have engaged with reconstruction in Australia, dealing with systems that necessitate reference to variation between Omaha and unskewed terminology at periods. These can lead to loss of skewed terminology and replacement with asymmetrical (male with matrilateral cousin) marriage (McConvell and Keen 2011), another significant type of change in Lévi-Strauss's evolutionary model. My research deals with actual forms of words and is a robust method in prehistory, not speculative. What is more conjectural perhaps is the association of the transition to Omaha with expansionary phases of groups. Similar patterns can be found in North America and New Guinea (McConvell 2012:258-260). The Omaha-expansion and related hypotheses could be candidates for treatment by a unified multisubdisciplinary approach, even perhaps for Muskogean, if the constraints against ethnohistorical and linguistic prehistory methods imposed by Ensor et al. were relaxed.

Australia is a continent in which most people did not build fixed dwellings. Yet camp areas were rigorously structured, and areas were set aside for burial. I do not despair of kinship 
archaeology and bioarchaeology in this context, but the sidelining of ethnohistory and linguistic prehistory by these authors would make a multisubdisciplinary effort more difficult.

\section{Peter N. Peregrine}

Anthropology and Museum Studies, Lawrence University, 711 East Boldt Way, Appleton, Wisconsin 54911, USA, and the Santa Fe Institute, 1399 Hyde Park Drive, Santa Fe, New Mexico 87501, USA (peter.n.peregrine@lawrence.edu).7 XII 16

In a time when archaeological genetics is revolutionizing the field of bioarchaeology and the analysis of skeletal remains is seen as a bit of a dying specialty, it is refreshing to read a paper that reminds us of how much we can learn from the detailed examination of morphological traits. It is also refreshing to see an archaeological paper that offers a nuanced approach to kinship far more in line with contemporary anthropology than the structural or biologically determined viewpoint commonly used in archaeology. A key reason that Ensor, Irish, and Keegan are able to provide this nuanced view is because they have read extensively in ethnography and have spent years thinking about how the often messy world of actual kinship practice might translate into the archaeological record. I am pleased to see that they have provided us with a clear picture of what they have learned.

I am also pleased to see that Ensor, Irish, and Keegan employed the eHRAF archive to help them in identifying ethnographic materials with which to examine variation in kinship practice. eHRAF is a powerful tool that is far underutilized by archaeologists. We have wrung our hands for generations over the problems of ethnographic analogy without realizing that eHRAF provides a way around that problem by providing a picture of the range of variation in practice that can be found in the ethnographic record. Through a comparative approach using eHRAF, we can identify generalizable patterns that should be broadly applicable to human cultures, and if we cannot do so, we can identify the range of practices that might be applicable to the archaeological cultures in which we are interested.

eHRAF also has an archive of archaeologically described cultures that we can use to uncover patterns or ranges of practice among ancient peoples. And with the readily available information in the eHRAF archaeology archive, we can compare ethnographically derived models of behavior with archaeologically derived ones to see empirically whether there are differences either in what is thought to be generalizable patterns or in the ranges of variation in practice that can be identified. This is powerful, for it not only allows us a way around the "tyranny of the ethnographic record" but also allows us to determine the biases that have been imposed on the archaeological record by interpretation based on ethnographic analogy. I thank Ensor, Irish, and Keegan for bringing attention to these important resources.
Michael A. Schillaci and Christopher M. Stojanowski

Department of Anthropology, University of Toronto Scarborough, Toronto, Ontario M1C 3H5, Canada (schillaci@utsc.utoronto.ca)/ School of Human Evolution and Social Change, Arizona

State University, Tempe, Arizona 85287, USA

(christopher.stojanowski@asu.edu).20 XII 16

Ensor and colleagues are correct that bioarchaeology faces important challenges when it comes to estimating kinship and postmarital residence from patterns of phenotypic variation. Although we are in strong agreement with the thrust of their paper, we have a number of comments, which we have structured around five major points. First, their models assume uniformitarianism based, presumably, on the repetition of patterns across geographically diverse populations, with similar rules of descent and residence. At the same time, they note the dramatic postcolonial effects of social engineering in the Americas. This raises the question of universality, and as such, their models should be used carefully.

Second, we think the authors are misreading the intent of bioarchaeologists. Researchers have generally not been interested in reconstructing kinship systems per se but rather in simply identifying close biological (not social) relatives. This is a major weakness of this literature, and determining why cointerments may be social but not genetic kin has not been a priority. The difference is one of trying to identify the presence of nuclear families in an ancient cemetery versus trying to establish the universality of the nuclear family. In bioarchaeology, patterns of biological relatedness are applied to broader questions about cemetery organization, ideologies of kinship and community, health, and political power, all requiring the integration of other lines of evidence (Johnson and Paul 2016).

Third, Ensor et al. assume that the methods in bioarchaeology are up to the task. Their figure 2 is a useful addition to the literature, but we are unconvinced of its utility in practice. There has actually been little methodological development for small-scale biodistance analysis, which has not leveraged genotypic association studies or inferences from developmental biology to better inform the meaning behind patterns of variation. Narrow-sense heritability estimates for dentition have not been published using maximum likelihood methods that would allow formal tests of genetic and environmental correlation. Recent work by Paul and Stojanowski (2015) shows that even siblings can be difficult to differentiate from unrelated individuals using phenotypic data. While it is true that siblings, on average, tend to be more similar to each other than expected by chance, this was not the case for many sibling dyads. If siblings are so difficult to identify, then establishing more distant familial genetic relationships is likely to be impossible.

Fourth, Ensor et al. provide models that align analytical outcomes with what is essentially a typology of kinship and social organization. However, the relevance and impact of doing so is not clear except to the extent that other cultural attributes 
package with rules of descent. This approach contrasts with that in Johnson and Paul (2016), which moves beyond the typological trappings of the past century and identifies future pathways that explore the "work" that kinship does in past societies as part of a broader exploration of the human life course.

Fifth, in their appraisal of biological approaches to estimating postmarital residence patterns, Ensor and colleagues rightly challenge the often-made assumption that spouses are buried together. They demonstrate that spouse burial location is most often determined by descent group membership and that spouses are buried together only with bilateral descent or when group membership is transferred. In cultures with unilineal descent without membership transfer, which is more common, spouses are returned to their natal descent group's cemetery. They also describe how marriage rules govern the distribution of phenotypic variation within and among descent group cemeteries, something that we did not consider in our research on postmarital residence at Pueblo Bonito in Chaco Canyon (Schillaci and Stojanowski 2003; Stojanowski and Schillaci 2006).

Ensor and colleagues make a strong case that the assumption of burial location and the failure to account for marriage rules represent serious flaws in bioarchaeology's treatment of postmarital residence thus far. Nonetheless, they make several critical assumptions in their critique of our inference of bilocality/patrilocality and endogamy at Pueblo Bonito. They point out, with reference to their figure 2 , that our observed pattern of biodistances within the cemeteries at Pueblo Bonito (Stojanowski and Schillaci 2006, fig. 11), which they describe as clustering among few males and females, is consistent with expectations for exogamous unilineal descent groups. Subjective determinations of "clustering" notwithstanding, the withinsex mean interindividual distances we presented in our table 3 suggest greater male clustering. The authors also suggest that the archaeological data, primarily the estimated domestic floor area (Ensor 2013a; Peregrine 2001), supports the inference of matrilocality with exogamous matrilineal descent groups. In making their inference, however, they assumed that postmortem location was not with the spouse and that the marriage rules prescribed exogamy, a consequence of choosing the Western Pueblos (e.g., Hopi and Zuni) as the ethnographic basis for their inference.

Biodistance analyses that we cite in our papers suggest that Chaco Canyon populations, including Pueblo Bonito, shared close genetic relationships with ancestral Tewa pueblos in the northern Rio Grande region of New Mexico. The Rio Grande Tewa exhibit what has been described as nonexogamous dual organization (summer and winter moieties), where a child is typically initiated into his/her father's moiety and a bride transfers to her husband's moiety (see Ortiz 1965). The primary social unit is the bilateral extended family, though there may be a bias toward patrilineality (Dozier 1955). Historically, residence was largely patrilocal (Dozier 1955). If we look to the Rio Grande Tewa for an ethnographic point of reference, rather than the unilineal clan descent of the Western Pueblos, then the pattern of biodistances at Pueblo Bonito could reasonably suggest bilocality/patrilocality. Also, the architectural pattern at Chaco cannot be interpreted as being indicative of matrilocality when we consider the domestic floor area and the configuration of ancestral Tewa pueblos. Although recent archaeogenomic research (Kennett et al. 2017) has demonstrated convincingly that, like the modern/historic Western Pueblos, Pueblo Bonito comprised at least one matrilineal descent group, thus refuting our results, we maintain that the assumptions Ensor and colleagues make in their critique of our research on postmarital residence at Chaco Canyon are problematic. In other words, they seem to have arrived at the right conclusions despite their methodology.

\section{Mikołaj Szołtysek}

Department of Resilience and Transformation in Eurasia, Historical Anthropology in Eurasia, Max Planck Institute for Social Anthropology, Advokatenweg 36, D-06114 Halle (Saale), Germany (szoltysek@eth.mpg.de).18 I 17

Ensor and the coauthors' major quibble has to do with some of the assumptions guiding interpretation of empirical artifacts in bioarchaeology, suggestive of what the authors perceive as a "lingering disconnect between bioarchaeological and anthropological perspectives." These include too much reliance on the concept of kinship as biological relatedness, long discarded in social anthropology; the notion of biological homogeneity of descent groups; the expectation that, in archaeological populations, spouses are universally buried together; and finally, insufficient attention paid to the role of marriage systems as crucial instigators of inner variation in gene flows. Their critical essay is a plea for the reinterpretation of these basic assumptions in an effort to fully capitalize on the otherwise-genuine bioarchaeological approaches to kinship, which - the argument goeshave a potential to further reinvigorate the anthropological understanding of kinship. Even for somebody from outside archaeology-anthropology tenets (such as myself), such motivation calls for nothing but a thorough appraisal. If bioarchaeology is to further enlighten the study of prehistoric family and kinship systems, assumptions used in making inferences from archaeological artifacts must be as realistic as possible. The stakes are set pretty high here - in fact, much higher than in explorations of family or residential and kinship histories, which "historical demographers" tend to deal with at a more "shallow" level, although there, too, a significant margin of error exists. When making inferences from data that are often very rough, imprecise, or fragmentary, the danger of projecting ahistorical and unviable categories and concepts back on the archaeological populations is, as Ensor et al. lucidly point out, much greater. Although the authors do not spell it out explicitly, it seems that the underlying motivation of the whole endeavor is to prevent the actual variation of human prehistoric organization and behavior from being obscured by unrealistic and homogenizing assumptions (e.g., the belief in inner biological 
homogeneity of lineage groups). This underlying plea for variation, if my observation is correct, is a very important issue, which the authors seem to be sharing with a much wider research community of population scientists and historical demographers (Szołtysek 2015a).

The authors' core argument regarding revisions to assumptions guiding the interpretation of the bioarchaeology of prehistoric social organization boils down to a simple but genuine case for better-informed inferences from archaeological artifacts based on the patterns established outside prehistoric archaeology (i.e., by cross-cultural research). Ensor and colleagues masterfully reverse a common causality loop (or feedback mechanism loop) and show, against the grain of the usual bioarchaeological reasoning, that, instead of deriving expectations about postmarital rules from biodistances, we should derive expectations about biodistances from cross-culturally observed descent rules and their bearing on postmortem location. However, it soon appears that much of the implementation of this rightly revisionist agenda relies on a table consisting of cross-cultural (eHRAF) data for only 28 cultures from around the world (roughly 15\% of Murdock's and White's "standard cross-cultural sample"). But do these 28 collected "cultures" from which cross-cultural "regularities," or expectations about them, are derived really give justice to overall human variability? A concerned reader cannot help but ask what biases might be involved and which caveats would apply.

Remain unconcerned by this little trench, and you will witness a stunning conceptual effort to establish idealized expectations for individual-level postmortem patterns from anthropological knowledge of major configurations of descent and postmarital residence rules (fig. 2). While I can imagine this to be a true milestone in properly systematizing the relationship between anthropological theory and archaeological practice regarding prehistoric kinship, the question arises regarding how empirical data are to be tested for compliance against these expected patterns. Only visually? What is the margin of error in measuring such a congruity or lack thereof? The authors do not provide any hint on that very practical question. Meanwhile, their exemplary elucidation of one expected pattern (for individual bilocal residential-household groups under bilateral descent, "most males and females should exhibit low biodistances [and] some males and some females should exhibit greater distances and greater heterogeneity") involves the danger of inviting haphazard interpretations, which cannot lead us far. There is a lesson to be learned in this regard from historical demography, where P. Laslett's early typology of European historical family systems by means of "sets of familial tendencies"-whose occurrence was accounted for by such vague terms as usually, sometimes, frequently, always, occasional, and so on - caused a lot of confusion before eventually being abandoned (Szołtysek 2015b).

There are several other potential cross-cuttings with population history, among which the prospect that at least some of the prehistoric dwellings might have been occupied by relatively small household-based groups (if not conjugal units with children) provides intriguing counterarguments to the alleged uniqueness of the conjugal/simple/nuclear family model so often ascribed to postmedieval western Eurasia in the historical demographic literature (Goody 1996). Yet, this dialogue may become difficult due to the dense anthropological terminology and incommensurable conceptualizations of the object of analysis. When reading Ensor and his colleagues' paper, we are confronted with "a corporate property-owning extended family," "corporate descent groups," "residential groups," "household groups," and - as if this were not enough already - also "residential-household groups." Although likely to be anthropologists' "daily bread," such variability in the basic forms of human political and economic organization, which is believed to have existed cross-culturally, stands in a stark contrast with historical demographers' much more circumscribed (or modest) focus on the coresident domestic group, one of the very few familial institutions relatively well recorded in historical archives (Szołtysek 2015b). But if this variation may cause a headache among historical demographers, it may also be impenetrable to archaeologists.

\section{Reply}

We thank our colleagues for their insightful comments and appreciate the opportunity provided by this venue to promote dialogue on such an important anthropological topic. The commenters generally agree that the ethnographically informed perspectives we emphasized could redirect bioarchaeological kinship research in positive ways. Our major points were that (1) kinship is not biological relatedness, (2) unilineal descent groups are not biologically homogeneous, (3) residence does not universally conform with postmortem location, and (4) marriage systems pattern phenotype distributions. These points were illustrated in generalized descriptions of kinship practices and exemplified with the ethnographic sample, which together provided information on intra- and intercemetery biodistance models for a range of kinship practices. They are nonbiological/ non-Western conceptual models called for by Johnson and Paul (2016).

Schillaci and Stojanowski state that we misread the intentions of bioarchaeologists - that "researchers have generally not been interested in reconstructing kinship systems per se but rather in simply identifying close biological (not social) relatives." The statement demonstrates a biological perspective on kinship. We disagree. Numerous bioarchaeological projectsnearly all of the works we cited, including Schillaci's and Stojanowski's - explicitly sought to understand social organization and/or postmarital residence using biodistance data, which can also extend to social identity research (Johnson and Paul 2016). Kinship is not reduced to genealogical relatedness in anthropology. In bioarchaeology, biodistance is a tool for interpreting culture, not an end in itself. 
McConvell suggests molecular genomics deserved more coverage. We intentionally focused on phenotypic traits because bioarchaeologists routinely rely on those data and will continue to do so alongside ancient DNA (aDNA), a different source of information. Indeed, we indicate that expected MDS plots for matrilineal and patrilineal descent groups without membership transfers should appear similar and that aDNA can distinguish the two. We also expect that the phenotypic models we advocate will complement genomic research.

McConvell and Schillaci and Stojanowski raise issues that relate to why bioarchaeological kinship research is necessary. We devote a good portion of our response to addressing this. McConvell claims we have devalued ethnological and historical linguistic approaches to prehistoric kinship. Our article addresses bioarchaeological approaches to kinship; it does not cover approaches across all subfields. More importantly, we stress that bioarchaeology can and should be a major producer of knowledge on kinship.

Ethnological tyranny (Maclachlan and Keegan 1990) is the archaeological/bioarchaeological consumption of potentially problematic ethnological characterizations, assumptions, and interpretations for interpreting prehistory; it perpetuates problems rather than using data to contribute new information. One form is ethnographic analogy (critiqued by Peregrine). For example, because Schillaci and Stojanowski assumed that peoples across time and space with genetic similarities should have the same kinship practices, they chose historically altered Tewa kinship as analogy for prehistoric Chaco Canyon. As one line of evidence, they interpreted kinship from ancestral Tewa Puebloan dwellings in accordance with the analogy, though not using the cross-culturally tested methods (Ensor 2013a:65; Peregrine and Ember 2002). They then interpreted their biodistance data from Pueblo Bonito in accordance with the analogy. Analogy led to what they now acknowledge was an incorrect conclusion. Another example would be the projection onto prehistory of historic kinship among the MuskogeanCreeks-during turbulent social disruptions from colonial impacts - when McConvell's discussion (and other ethnohistoric analyses confirming matrilocality; e.g., Moore and Campbell 2002) indicates disagreement over historic social organization. For clarification, Muskogean Creeks were not analyzed in Ensor (2013a) or our article.

Another form of ethnological tyranny is the consumption of ethnological interpretations guided by problematic highlevel theories (see Ensor 2017). Ethnological approaches to prehistoric kinship use long-discarded unilinear neoevolutionism (i.e., speculative sequences of abstract kin-term models) to interpret prehistoric kinship from modern/historic kin terminology. The data do not date to prehistory but are assumed products of prehistoric evolutionary sequence. Phylogenetics commonly guides historical linguistic approaches. The comparative method using modern/historic kin-term semantics inevitably results in clustering based on similarities and differences. Such clusters are assumed, in accordance with the model, to be nodes branching from "proto-kinship." Moore (1994) warned about phylogenetics: cumulative anthropological knowledge demonstrates that culture does not change in those ways (see also Armelagos and Van Gerven 2003; Campbell and Poser 2008). Additional problems using kin terminology are normative models for cultures when internal communities differ (Moore 1988) and problematic structural-functionalist leaps from nomenclature to interpret social organization (acknowledged by McConvell). Ethnological/historical linguistic statements on prehistory certainly have a role. However, because they are theoretically guided interpretations, not objective "reconstructions," independent testing by subfields with materials actually dating to the periods in question is needed.

To avoid ethnological tyranny, bioarchaeology requires midlevel theories associating kinship practices to specific biodistance patterns. Bioarchaeologists have been doing this in their kinship research - for example, in the assumption that intracemetery female homogeneity, male heterogeneity, and pooled sex differences indicate matrilocality (e.g., Konigsberg 1988) although we suggest that the pattern identifies matrilocality under bilateral descent. Such generalizable associations are not biased by ethnological interpretations from analogy or evolutionary models. Instead, the generalizable associations allow bioarchaeology to contribute plausible inferences using biodistance data from cemeteries that actually date to the prehistoric periods under study.

Exemplifying the use of midlevel theory, we indicate that Schillaci's and Stojanowski's MDS plot from Pueblo Bonito could be interpreted as a cemetery for a unilineal descent group, based on the generalizable pattern described in our article. Additionally, the archaeological dwelling sizes and layout at Pueblo Bonito conform with cross-culturally tested and confirmed exclusive patterns for matrilocality (Peregrine 2001) and unilineal descent groups, which together indicate matrilineal descent groups (Ensor 2013a). These methods are informed by cross-cultural generalization applied to prehistoric data from Pueblo Bonito and are independent of analogy, ethnological interpretation, or theoretical biases. We note here Kennett and coworkers' (2017) genomic evidence for another matrilineal descent group at Pueblo Bonito.

Schillaci and Stojanowski maintain that our proposed models are "uniformitarian" based on the repetition of patterns across geographical regions (i.e., it is defensible that unilineal descent groups are not biologically homogeneous). In regard to descent and postmortem location, a preferable label is "crosscultural regularity." The stronger the cross-cultural association between a distinct practice and distinct material pattern, the greater the confidence in interpreting the former from the latter. Although previously aware that descent group membership, not residence, influences postmortem practices (e.g., Keegan 2009), we used the eHRAF for a sample of cultures to illustrate postmortem location with matrilineal descent groups, patrilineal descent groups, patrilineal descent groups with women's membership transferal (an indicator of extreme gender inequality), and bilateral descent. As Szołtysek rightly points out, a sample of 28 cultures provides an insufficient test of genera- 
lizations. We acknowledged this - the eHRAF search provided examples of our assertions on postmortem location, not a robust cross-cultural test. A broader cross-cultural test, which we encourage, would require more cases. Nevertheless, from those ethnographic patterns of kinship and postmortem location and the influences of marital practices, we modeled intra- and intercemetery expectations for biodistance data for the varied practices with large (fig. 2) and small cemeteries.

Schillaci and Stojanowski suggest we are aligning analytical outcomes with a typology of kinship and social organization. Kinship is an institution (Keegan 2016) that structures social organization, social relations, and social identity - a powerful tool for understanding human agency and interactions - that is not determined by biology, genealogy, mode of production, or environment (Keegan and Maclachlan 1989). Only by ignoring what kinship is and is not (Sahlins 2013) can one conclude that the analytical outcomes are aligned with a typology.

Szołtysek is similarly concerned about our characterization of bilocal residential households (a product of practices), which was treated as a social type in European historical demography. Bilocal residence is a flexible strategy whereby individuals negotiate a myriad of group membership/residential opportunities. One cannot predict which individuals will reside with which close biological relations. The composition of one bilocal residence may differ from one next door. To attempt definitions of which and how many close biological relations reside together through bilocality misses the point of the practice.

Szołtysek questions how biodistance data can be used for interpreting kinship (i.e., "only visually?"). We chose MDS plots for illustrative purposes because they are commonly used in bioarchaeological research and easily interpretable by nonspecialists. We also relied on Howell's and Kintigh's mapping of biodistance clusters. That said, as mentioned in our paper, many quantitative approaches are available to statistically test "for compliance against these expected patterns," including a wide range of distance measures dependent upon the level of data used (e.g., Bedrick, Lapidus, and Powell 2000; Irish 2010; Konigsberg 1990, 2006; Relethford and Blangero 1990; Relethford and Lees 1982; Sjøvold 1977; Stojanowski and Schillaci 2006).

Schillaci and Stojanowski point out difficulties in identifying biological siblings with biodistance measures and question whether bioarchaeological methods are up to task. Stojanowski, in particular, has worked extensively in this area. That said, the question demonstrates a biological perspective on kinship. The point should not be to interpret individual biological siblings per se but to interpret social organization, residence, and identities. Biodistance clustering in phenotypic traits occurs and needs to be explained. For example, our model for matrilineal descent groups merely anticipates intra- and intercemetery biodistance clustering, which is exactly what Howell's and Kintigh's (1996) results from Hawikku demonstrate.

In sum, we hope the intent of our paper is patent - to present alternative views on kinship as a means to invite dialogue. We believe bioarchaeologists are uniquely positioned and meth- odologically equipped to work across subfields and provide new interpretations on prehistoric kinship. We look forward to future discourse with our colleagues, with a goal of further advancing bioarchaeology's contributions to the anthropological study of kinship. Finally, we wish to honor John H. Moore (1939-2016), who took a keen interest in ethnographically informed models for the study of prehistory.

-Bradley E. Ensor, Joel D. Irish, and William F. Keegan

\section{References Cited}

Aguiar, Gilberto de Souza, and Walter Alvez Neves. 1991. Postmarital residence pattern and within-sex genetic diversity among the Urubu-Ka'apor Indians, Brazilian Amazon. Human Biology 63:467-488.

Ahmed, Akbar S. 1980. Pukhtun economy and society: traditional structure and economic development in a tribal society. Boston: Routledge \& Kegan Paul.

Alt, Kurt W., Sandra Pichler, Werner Vach, Bohuslav Klíma, Emanuel Vlček, and Jürg Sedlmeier. 1997. Twenty-five thousand-year-old triple burial from Dolní Věstonice: an ice-age family? American Journal of Physical Anthropology 102:123-131.

Alt, Kurt W., and Werner Vach. 1995. Odontologic kinship analysis in skeletal remains: concepts, methods, and results. Forensic Science International 74: 99-113.

. 1998. Kinship studies in skeletal remains: concepts and examples. In Dental anthropology: fundamentals, limits, and prospects. Kurt W. Alt, Friedrich W. Rösing, and Maria Teschler-Nicola, eds. Pp. 537-554. Vienna, Austria: Springer.

Armelagos, George J., and Dennis P. Van Gerven. 2003. A century of skeletal biology and paleopathology: contrasts, contradictions, and conflicts. American Anthropologist 105:51-62.

Barth, Fredrik. 1965. Political leadership among Swat Pathans. London: Athlone. Bastian, Misty L. 1992. The world as marketplace: historical, cosmological, and popular constructions of the Onitsha market system. Ann Arbor, MI: UMI Dissertation Services.

Beaglehole, Ernest. 1941. Pangai: village in Tonga. Wellington, New Zealand: Polynesian Society.

Bedrick, E. J., J. Lapidus, and J. F Powell. 2000. Estimating the Mahalanobis distance from mixed continuous and discrete data. Biometrics 56:394401.

Bouwman, Abigail. 2014. The different aspects of aDNA in establishing kinship. Paper presented at the 79th Annual Meeting of the Society for American Archaeology, Austin, Texas, April 23-27.

Campbell, Lyle, and William J. Poser. 2008. Language classification: history and method. Cambridge: Cambridge University Press.

Carr, Christopher. 1995. Mortuary practices: their social, philosophicalreligious, circumstantial, and physical determinants. Journal of Archaeological Method and Theory 2:105-200.

Cole, John Tafel. 1969. The human soul in the Aymara culture of Pumasara: an ethnographic study in the light of George Herbert Mead and Martin Buber. Ann Arbor, MI: University Microfilms.

Collier, Jane F., and Sylvia J. Yanagisako, eds. 1987. Gender and kinship: essays toward a unified analysis. Stanford, CA: Stanford University Press.

CSAC (Centre for Social Anthropology and Computing, University of Kent at Canterbury). 2017. Ethnographic atlas crosstabulations. http://lucy.ukc.ac .uk/cgi-bin/uncgi/ethnoatlas/atlas.vopts. [PM]

De Laguna, Frederica. 1972. Under Mount Saint Elias: the history and culture of the Yakutat Tlingit. Washington, DC: Smithsonian Institution Press.

Dozier, Edward. 1955. Kinship and linguistic change among the Arizona Tewa. International Journal of American Linquistics 21:242-257. [MAS/CMS]

Driver, Harold E., and William C. Massey. 1957. Comparative studies of North American Indians. Philadelphia: American Philosophical Society.

Eggan, Fred. 1937. Historical changes to the Choctaw kinship system. American Anthropologist 39(1):34-52. [PM]

. 1966. The American Indian. Chicago: Aldine.

Ellison, James. 2009. Governmentality and the family: neoliberal choices and emergent kin relations in Southern Ethiopia. American Anthropologist 111: 81-92.

Ember, Carol R., and Melvin Ember. 1972. The conditions favoring multilocal residence. Southwestern Journal of Anthropology 28:382-400. 
Ember, Melvin, and Carol R. Ember. 1971. The conditions favoring matrilocal versus patrilocal residence. American Anthropologist 73:571-594.

Ensor, Bradley E. 2003. Kinship and marriage among the Omaha, 1886-1902. Ethnology 42:1-14

. 2011. Kinship theory in archaeology: from critiques to the study of transformations. American Antiquity 76:203-227.

. 2013a. The archaeology of kinship: advancing interpretation and contributions to theory. Tucson: University of Arizona Press.

2013b. The crafting of prehispanic Maya kinship. Tuscaloosa: University of Alabama Press.

- 2014. Discussant, "Bioarchaeological approaches to kinship: bridging biology, social relatedness, and theory." Paper presented at the 79th Annual Meeting of the Society for American Archaeology, Austin, Texas, April 2327.

2017. Testing ethnological theories on prehistoric kinship. CrossCultural Research 51:1-29.

Fenton, William N. 1951. Locality as a basic factor in the development of Iroquois social structure. Bureau of American Ethnology Bulletin 149:35-54.

Filipovic, Milenko S. 1982. Among the people, native Yugoslav ethnography: selected writing of Milenko S. Filipovic. Ann Arbor: Michigan Slavic Publications, Department of Slavic Languages and Literatures.

Fortes, Meyer. 1945. The dynamics of clanship among the Tallensi: being the first part of an analysis of the social structure of a Trans-Volta Tribe. London: Oxford University Press.

. 1950. Kinship and marriage among the Ashanti. In African systems of kinship and marriage. A. R. Radcliffe-Brown and D. Forde, eds. Pp. 252284. London: Oxford University Press.

1959. Primitive kinship. Scientific American 200(6):146-158.

Fox, Robin. 1967. Kinship and marriage: an anthropological perspective. Cambridge: Cambridge University Press.

Franklin, Sarah, and Susan McKinnon, eds. 2001. Relative values: reconfiguring kinship studies. Durham, NC: Duke University Press.

Gillespie, Susan D. 2000a. Beyond kinship: an introduction. In Beyond kinship: social and material reproduction in house societies. Rosemary A. Joyce and Susan D. Gillespie, eds. Pp. 1-21. Philadelphia: University of Pennsylvania Press.

. 2000b. Rethinking ancient Maya social organization: replacing "lineage" with "house." American Anthropologist 102:467-484.

Gjessing, Gutorm. 1956. Socio-culture: interdisciplinary essays on society and culture. Oslo, Norway: Studies Honouring the Centennial of Universitetes Etnografiske Museum.

- 1975. Socio-arcaheology. Current Anthropology 16:323-341.

Gluckman, Max. 1941. Economy of the Central Barotse Plain. Livingstone: Rhodes-Livingstone Institute.

Godelier, Maurice. 2011. The metamorphoses of kinship. New York: Verso.

Goldstein, Lynn G. 1981. One-dimensional archaeology and multi-dimensional people: spatial organization and mortuary analysis. In The archaeology of death. Robert Chapman, Ian Kinnes, and Klavs Randsborg, eds. Pp. 53-70. Cambridge: Cambridge University Press.

Goody, J. 1996. Comparing family systems in Europe and Asia: are there different sets of rules? Population and Development Review 22(1):1-20. [MS]

Gough, Kathleen. 1961. Variation in residence. In Matrilineal kinship. David M. Schneider and Kathleen Gough, eds. Pp. 545-576. Berkeley: University of California Press.

Gutierrez de Pineda, Virginia, and Sydney J. Muirden. 1948. Social organization in La Guajira. New Haven, CT: Human Relations Area Files.

Han, Chungnim C. 1970. Social organization of upper Han Hamlet in Korea. Ann Arbor, MI: University Microfilms.

Hirschon, Renee. 1989. Heirs of the Greek Catastrophe: the social life of Asia Minor refugees in Piraeus. Oxford: Oxford University Press.

Hoffman, Bernard G. 1967. The structure of traditional Moroccan rural society. The Hague, Netherlands: Mouton.

Hough, Walter. 1899. Korean clan organization. American Anthropologist 1:150-154.

Howell, Todd L., and Keith W. Kintigh. 1996. Archaeological identification of kin groups using mortuary and biological data: an example from the American Southwest. American Antiquity 61:537-554.

Hubbe, Mark, Walter Alves Neves, Emiliano Castro de Oliveira, and André Strauss. 2009. Postmarital residence practice in Southern Brazilian coastal groups: continuity and change. Latin American Antiauity 20:267-278.

Hulstaert, Gustave E., and Monika B. Vizedom. 1938. Marriage among the Nkundu. Brussels, Belgium: Librairie Falk.
Hunt, Muriel Eva Verbitsky. 1962. The dynamics of the domestic group in two Tzeltal villages: a contrastive comparison. $\mathrm{PhD}$ dissertation, University of Chicago.

Hurault, Jean, and Jean Winchell. 1961. The Boni refugee Blacks of French Guiana. Dakar, Senegal: IFAN.

Hutchinson, Sharon E. 1996. Nuer dilemmas: coping with money, war, and the state. Berkeley: University of California Press.

Irish, Joel D. 2010. The mean measure of divergence (MMD): its utility in model-free and model-bound analyses relative to the Mahalanobis $\mathrm{D}^{2}$ distance for nonmetric traits. American Journal of Human Biology 22:378-395.

Janelli, Roger L., and Dawnhee Yim Janelli. 1982. Ancestor worship and Korean society. Stanford, CA: Stanford University Press.

Johnson, Kent, and Kathleen Paul, organizers. 2014. Bioarchaeological approaches to kinship: bridging biology, social relatedness, and theory. Abstracts of the Society for American Archaeology 79th Annual Meeting, Austin, Texas, April 23-27. http://www.saa.org/Portals/0/SAA/Meetings/2014 $\% 20$ Abstracts/Session_Abstracts.pdf.

2016. Bioarchaeology and kinship: integrating theory, social relatedness, and biology in ancient family research. Journal of Archaeological Research 24:75-123. [MAS/CMS]

Jones, Doug, and Bojka Milicik, eds. 2011. Kinship, language, and prehistory: Per Hage and the renaissance in kinship studies. Salt Lake City: University of Utah Press.

Kaut, Charles R. 1957. The Western Apache clan system: its origins and development. Albuquerque: University of New Mexico Press.

Keegan, William F. 2006. All in the family: descent and succession in the protohistoric chiefdoms of the Greater Antilles - a comment on Curet. Ethnohistory 53:383-392.

2009. Central plaza burials in Saladoid Puerto Rico: an alternative perspective. Latin American Antiquity 20:375-385.

2016. Kinship as instituted process. Paper presented at the 81st annual meeting of the Society for American Archaeology, Orlando, Florida, April 6-10.

Keegan, William F., and Morgan D. Maclachlan. 1989. The evolution of avunculocal chiefdoms: a reconstruction of Taino kinship and politics. American Anthropologist 91:613-630.

Keesing, Roger M. 1975. Kin groups and social structure. New York: Holt, Rinehart \& Winston.

Kennett, Douglas J., Stephen Plog, Richard J. George, Brenden J. Culleton, Adam S. Watson, Pontus Skoglund, Nadin Rohland, et al. 2017. Archaeogenomic evidence reveals prehistoric matrilineal dynasty. Nature Communications 8:14115. [MAS/CMS]

Konigsberg, Lyle W. 1988. Migration models of prehistoric postmarital residence. American Journal of Physical Anthropology 77:471-482.

- 1990. Analysis of prehistoric biological variation under a model of isolation by geographic and temporal distance. Human Biology 62:49-70.

. 2006. A post-Neumann history of biological and genetic distance studies in bioarchaeology. In Bioarchaeology: the contextual analysis of human remains. Jane E. Buikstra and Lane A. Beck, eds. Pp. 263-279. New York: Academic Press.

Kopytoff, Igor, Robert Mayfield, Ruth C. Heffner, and Thomas A. Sebok. 1955. The Samoyed. New Haven, CT: Human Relations Area Files.

Korotayev, Andrey. 2003. Form of marriage, sexual division of labor, and postmarital residence in cross-cultural perspective: a reconsideration. Iournal of Anthropological Research 59:69-89.

Kruskal, Joseph B., and Myron Wish. 1978. Multidimensional scaling. Beverly Hills, CA: Sage.

Kuper, Adam. 1982. Lineage theory: a critical retrospect. Annual Review of Anthropology 11:71-95.

Lane, Rebecca A., and Audrey J. Sublett. 1972. Osteology of social organization: residence pattern. American Antiquity 37:186-201.

Lévi-Strauss, Claude. 1956. The family. In Man, culture, and society. Harry L. Shapiro, ed. Pp. 261-285. New York: Oxford University Press.

. 1965. The future of kinship studies. Proceedings of the Roval An thropological Institute of Great Britain and Ireland 1965:13-22.

1969. The elementary structures of kinship. Boston: Beacon. 1982. The way of the masks. Seattle: University of Washington Press. Lutfiyya, Abdulla M. 1966. Baytiin a Jordanian village: a study of social institutions and social change in a folk community. The Hague, Netherlands: Mouton.

Maclachlan, Morgan D., and William F. Keegan. 1990. Archaeology and the ethno-tyrannies. American Anthropologist 92:1011-1013. 
Marshall, Maureen. 2014. 'Sharing death': double interments in the Late Bronze Age South Caucasus. Paper presented at the 79th Annual Meeting of the Society for American Archaeology, Austin, Texas, April 23-27.

McConvell, Patrick. 2012. Omaha skewing in Australia: overlays, dynamism and change. In Crow-Omaha: new light on a classic problem of kinship analysis. T. R. Trautmann and P. M. Whiteley, eds. Pp. 243-260. Tucson: University of Arizona Press. [PM]

McConvell, Patrick, and Ian Keen. 2011. The transition from Kariera to an asymmetrical system: Cape York Peninsula to North-East Arnhem Land. In Kinship, language and prehistory: Per Hage and the renaissance in kinship studies. D. Jones and B. Milicic, eds. Pp. 99-132. Salt Lake City: University of Utah Press. [PM]

McConvell, Patrick, Ian Keen, and Rachel Hendery, eds. 2013. Kinship systems: change and reconstruction. Salt Lake City: University of Utah Press.

Mcllwraith, Thomas F. 1948. The Bella Coola Indians: volume one. Toronto: University of Toronto Press.

McKnight, David. 2004. Going the Whiteman's way: kinship and marriage among Australian Aborigines. Aldershot, UK: Ashgate.

Meyer, William. 2014. Discussant, "Establishing a bioarchaeology of community." Paper presented at the 79th Annual Meeting of the Society for American Archaeology, Austin, Texas, April 23-27.

Moore, John H. 1988. The dialectics of Cheyenne kinship: variability and change. Ethnology 27:253-269.

. 1994. Putting anthropology back together again: the ethnogenetic critique of cladistic theory. American Anthropologist 96:925-948.

Moore, John H., and Janis E. Campbell. 2002. Confirming unilocal residence in Native North America. Ethnology 41:175-188.

Murdock, George P. 1949. Social structure. New York: Macmillan.

Ortiz, Alfonso. 1965. Dual organization as an operational concept in the Pueblo Southwest. Ethnology 4:389-396. [MAS/CMS]

Parman, Susan. 1972. Sociocultural change in a Scottish Crofting township. Ann Arbor, MI: University Microfilms.

Pasternak, Burton. 1976. Introduction to kinship and social organization. Englewood Cliffs, NJ: Prentice-Hall.

Peletz, Michael G. 1995. Kinship studies in late twentieth-century anthropology. Annual Review of Anthropology 24:343-372.

Peregrine, Peter N. 2001. Matrilocality, corporate strategy, and the organization of production in the Chacoan world. American Antiquity 66:36-46.

Peregrine, Peter N., and Melvin Ember. 2002. Response to Schillaci and Stojanowski. American Antiquity 67:357-359.

Price, Richard. 1975. Saramaka social structure: analysis of a maroon society in Surinam. Rio Piedras: Institute of Caribbean Studies, University of Puerto Rico.

Prokof'eva, E. D., Maksim G. Levin, and Leonid P. Potapov. 1964. The Nentsy. In The peoples of Siberia. Maksim G. Levin and Leonid P. Potapov, eds. Pp. 547-570. Chicago: University of Chicago Press.

Rattray, Robert S. 1929. Ashanti law and constitution. Oxford: Clarendon.

Relethford, John H., and J. Blangero. 1990. Detection of differential gene flow from patterns of quantitative variation. Human Biology 62:5-25.

Relethford, John H., and F. C. Lees. 1982. The use of quantitative traits in the study of human population structure. Yearbook of Physical Anthropology 25:113-132.

Saxe, Arthur A. 1970. Social dimensions of mortuary practices in a Mesolithic population from Wadi Halfa, Sudan. PhD dissertation, University of Michigan, Ann Arbor.

Sahlins, Marshall D. 2013. What kinship is - and is not. Chicago: University of Chicago Press.

Scheffler, Harold W. 2001. Filiation and affiliation. Boulder, CO: Westview.
Schillaci, Michael A., and Christopher M. Stojanowski. 2002. A reassessment of matrilocality in Chacoan culture. American Antiquity 67:343-356.

2003. Postmarital residence and biological variation at Pueblo Bonito. American Journal of Physical Anthropology 120:1-15.

Schneider, David M. 1984. A critique of the study of kinship. Ann Arbor: University of Michigan Press.

Schram, Louis. 1932. Marriage among the T'u-jen of Kansu (China). Shanghai, China: Catholic Mission.

- 1954. The Monguors of the Kansu-Tibetan frontier: their origin, history and social organization. Philadelphia: American Philosophical Society.

Scott, G. Richard, and Christy G. Turner II. 1997. The anthropology of modern human teeth: dental morphology and its variation in recent human populations. Cambridge: Cambridge University Press.

Seidel, Andrew, and Kristin Nado. 2014. Changing conceptualizations of kinship among the Post-Meroitic and Christian period Nubians from the 4th Cataract Region, Sudan. Paper presented at the 79th Annual Meeting of the Society for American Archaeology, Austin, Texas, April 23-27.

Shternberg, Lev I. A. 1933. The Gilyak, Orochi, Goldi, Negidal, Ainu: articles and materials. Khabarovsk, Russia: Dal'giz.

Sjøvold T. 1977. Non-metrical divergence between skeletal populations: the theoretical foundation and biological importance of C.A.B. Smith's mean measure of divergence. Ossa 4(suppl. 1):1-133.

Spence, Michael W. 1974. Residential practices and the distribution of skeletal traits in Teotihuacan, Mexico. Man 9:262-273.

Stefan, Vincent H. 1999. Craniometric variation and homogeneity in prehistoric/protohistoric Rapa Nui (Eastern Island) regional populations. American Journal of Physical Anthropology 110:407-419.

Stojanowski, Christopher M., and Kathleen S. Paul. 2015. Performance analysis of deciduous morphology for detecting biological siblings. American Journal of Physical Anthropology 157:615-629. [MAS/CMS]

Stojanowski, Christopher M., and Michael A. Schillaci. 2006. Phenotypic approaches for understanding patterns of intracemetery biological variation. Yearbook of Physical Anthropology 131(suppl. 43):49-88.

Stout, David B. 1947. San Blas Cuna acculturation: an introduction. New York: Viking Fund.

Szołtysek, M. 2015a. Households and family systems in early modern Europe. In Peoples and places, vol. 1 of The Oxford handbook of early modern European history, 1350-1750, vol. 1: peoples and place. Hamish Scott, ed. Pp. 313341. Oxford: Oxford University Press. [MS ]

.2015b. Rethinking east-central Europe: family systems and co-residence in the Polish-Lithuanian Commonwealth. Population, Famille et Société, vol. 21. Bern, Switzerland: Lang. [MS]

Tomczack, Paula D., and Joseph F. Powell. 2003. Postmarital residence practices in the Windover population: sex-based dental variation as an indicator of patrilocality. American Antiquity 68:93-108.

Urban, Greg, and Jason B. Jackson. 2004. Social organization. In Southeast, vol. 14 of The handbook of North American Indians. R. D. Fogelson and W. Sturtevant, eds. Pp. 697-706. Washington, DC: Smithsonian Institution. [PM]

Usher, Bethany, and Jaimin Weets. 2014. Identifying kinship patterns in Anabaptist cemeteries: modeling archaeological graveyards. Paper presented at the 79th Annual Meeting of the Society for American Archaeology, Austin, Texas, April 23-27.

Wedgwood, Camilla H. 1943. Notes on the Marshall Islands. Oceania 13:123.

Zakrzewski, Sonia. 2014. Kinship, identity, and ancient Egyptian bioarchaeological relatedness. Paper presented at the 79th Annual Meeting of the Society for American Archaeology, Austin, Texas, April 23-27. 